\title{
MONETARY POLICY IN RESOURCE-RICH DEVELOPING ECONOMIES
}

\author{
Ruslan Aliyev
}
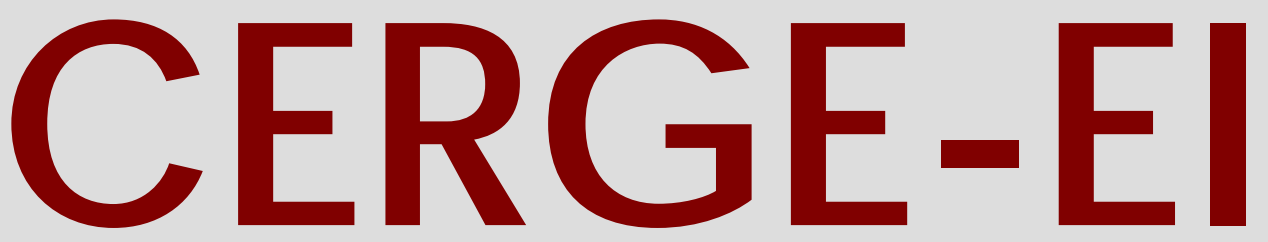

Charles University Centerfor Economic Research and Graduate Education Academy of Sciences of the Czech Republic Ec onomic s Institute 


\title{
Working Paper Series 466 (ISSN 1211-3298)
}

\section{Monetary Policy in Resource-Rich Developing Economies}

\author{
Ruslan Aliyev
}

CERGE-EI

Prague, August 2012 
ISBN 978-80-7343-270-6 (Univerzita Karlova. Centrum pro ekonomický výzkum a doktorské studium)

ISBN 978-80-7344-262-0 (Národohospodářský ústav AV ČR, v.v.i.) 


\title{
Monetary Policy in Resource-Rich Developing Economies
}

\author{
Ruslan Aliyev
}

\begin{abstract}
The economic literature acknowledges that to avoid the resource curse, resourcerich countries should restrict fiscal expansion and save a significant part of resource revenues outside the domestic economy. However, in these countries governments tend to ineffectively spend a considerable part of windfall revenues in the short run. In this research I construct a DSGE model for a small, open economy to show that if fiscal indiscipline in the form of immediate responses to foreign resource revenue changes is inevitable, then monetary policy can help improve the allocation problem. The simulation results indicate that targeting the exchange rate or price level through foreign exchange interventions by the central bank can soften the negative effects of Dutch Disease and stabilize the economy in the face of volatile natural resource revenues in the short run. I also find that a fixed exchange rate regime outperforms price level targeting by delivering higher isolation and hence less vulnerability to shocks in natural resource revenues. In contrast, if the central bank chooses to pursue a laissez faire policy, i.e., not to intervene, then the economy becomes vulnerable to shocks in foreign resource revenues and the resource curse becomes more severe.
\end{abstract}

JEL classification: E52, E63, F4.

Keywords: monetary policy, Dutch disease, resource-rich countries, macroeconomic stabilization.

I am grateful to Byeongju Jeong for his guidance and advice. I also thank Michal Kejak, Jan Kmenta, Sergey Slobodyan and Evangelia Vourvachaki for valuable comments and helpful suggestions. I am thankful to Sarah Peck and Richard Stock for English editing. All errors remaining in this text are the responsibility of the author.

This research was supported by a grant from the CERGE-EI Foundation under a program of the Global Development Network. All opinions expressed are those of the author and have not been endorsed by CERGE-EI or the GDN.

Center for Economic Research and Graduate Education-Economics Institute, a joint workplace of Charles University in Prague and the Academy of Sciences of the Czech Republic. Address: CERGE-EI, P.O. Box 882, Politických veznu 7, Praha 1, 111 21, Czech Republic. Email: Ruslan.Aliyev@cerge-ei.cz. 


\begin{abstract}
Abstrakt
Ekonomická literatura uznává, že pro to, aby se země bohaté na nerostné suroviny vyhnuly tzv. prokletí zdrojů, měly by omezit fiskální expanzi a uložit značnou část pár příjmů z nerostů mimo domácí ekonomiku. V těchto zemích ale vlády mají tendenci neefektivně utrácet významnou část příjmů v krátkém období. V tomto výzkumu vytváŕím DSGE model pro malou otevřenou ekonomiku, abych ukázal, že pokud fiskální nedisciplína ve formě okamžité reakce na změny v zahraničních př́jmech ze surovin je nevyhnutelná, pak monetární politika může pomoci zlepšit problém alokace. Výsledky simulace indikují, že cílení směnného kurzu nebo cenové úrovně pomocí kurzovních intervencí centrální banky může zmírnit negativní efekty Holandské nemoci a stabilizovat ekonomiku ve světle nestálých příjmů z nerostných surovin v krátkém období. Dále zjištuji, že režim fixních směnných kurzů má lepší výsledky než cílení cenové úrovně tím, že přináší vyšší izolaci a proto nižší náchylnost k šokům v př́jmech z nerostných surovin. Pokud se naopak centrální banka rozhodne pro laissez-faire politiku, tj. ne-intervenci, pak se ekonomika stává náchylnou $\mathrm{k}$ šokům v zahraničních příjmech z nerostných surovin a prokletí zdrojů se stává ještě silnějším.
\end{abstract}




\section{Introduction}

A large stream of research finds evidence that sustainable economic development of resource-rich countries is challenged by their ability to efficiently absorb revenues from resource exports. For instance, it has been documented that there is a negative relationship between natural-resource abundance and economic growth (Sachs and Warner 1995, 2001; Auty 1993, 2001a). In face of this challenge, the future development of a resource-rich economy heavily depends on the successful formulation of policy with regards to the revenues from natural resource exports. The key for this success is the restriction of fiscal expansion and saving a significant part of natural resource revenues abroad (Barnett and Ossowski, 2003; Davis et al., 2003; Segura 2006). However, the experience of resource-rich developing countries shows that in these countries political pressure is often directed toward spending the revenues from resource exports (Aliyev, 2012; Hermann, 2006). The government's increased fiscal spending of these revenues creates appreciation pressure on the domestic currency. This increases the imports of tradable goods, and decreases the competitiveness of the domestic manufacturing sector. In the economic literature it is called Dutch Disease, a situation observed in most resource-rich economies (Corden and Neary, 1982; Corden, 1984; Wijnbergen, 1984). Besides this syndrome such government policy makes these countries vulnerable to the volatility in the world prices of exported commodities and the exhaustibility of natural resources.

Under these circumstances the question arises whether monetary policy plays a significant role in the reallocation of natural resource revenues, and if so, what monetary regimes deliver better outcomes? Natural resource exporting countries vary in their exchange rate arrangements from fully fixed to independently floating monetary regimes, and there are endless discussions over the appropriateness of these regimes. This paper aims to contribute to this debate by evaluating three monetary

regimes in a small, developing economy facing volatile and uncertain revenues from natural resource exports: (i) fixed exchange rate, (ii) price level targeting, and (iii) laissez-faire. The main finding is that if fiscal indiscipline in the form of immediate responses to foreign resource revenue changes is inevitable, then certain monetary 
actions can help improve the allocation problem. In particular, targeting the exchange rate or price level through foreign exchange interventions by the central bank allows for consumption smoothing and avoiding the negative effects of Dutch Disease. Also due to higher intensity in using foreign exchange interventions, the fixed exchange rate regime outperforms price level targeting by delivering higher isolation and hence smaller vulnerability to shocks in foreign revenues. In contrast if the central bank chooses a laissez faire policy, more revenues are spent and the domestic economy becomes more vulnerable to shocks in foreign revenues.

Such an interaction between fiscal and monetary policies can be described by a game consisting of two players: fiscal and monetary authorities (Figure 1). In this game the fiscal authority can choose between two possible policies: it can behave either in a disciplined or in an undisciplined way. Under disciplined behavior, which is opposite the undisciplined one, the fiscal authority does not respond immediately to changes in natural resource revenues. The monetary authority sets one of the three possible monetary regimes described above. In this game the first best solution is achieved when the fiscal authority behaves in a disciplined way regardless of the implemented monetary policy. I also seek to determine the optimal monetary regime under the assumption that the fiscal authority always chooses an undisciplined strategy, which is very common among developing countries. The interesting finding is that the second and the third best solutions are achieved when the monetary authority chooses a fixed exchange rate and a fixed price level regime respectively, taking into account the advantages of these regimes in consumption smoothing. The worst outcome is achieved with a laissez faire policy.

Assumption about the purely undisciplined fiscal authority is made to model a stylized version of the situation observed in some oil exporting countries. I also hypothetically assume a government which never deviates its fiscal spending from the long run equilibrium level. However in real life optimal spending lies somewhere in between these two extremes. Here one can also think of a disciplined policy where the government moderately increases spending during a period of high natural resource revenues and moderately decreases it during a period of low or zero 
Figure 1: Normal form representation of the game between the fiscal and monetary authorities

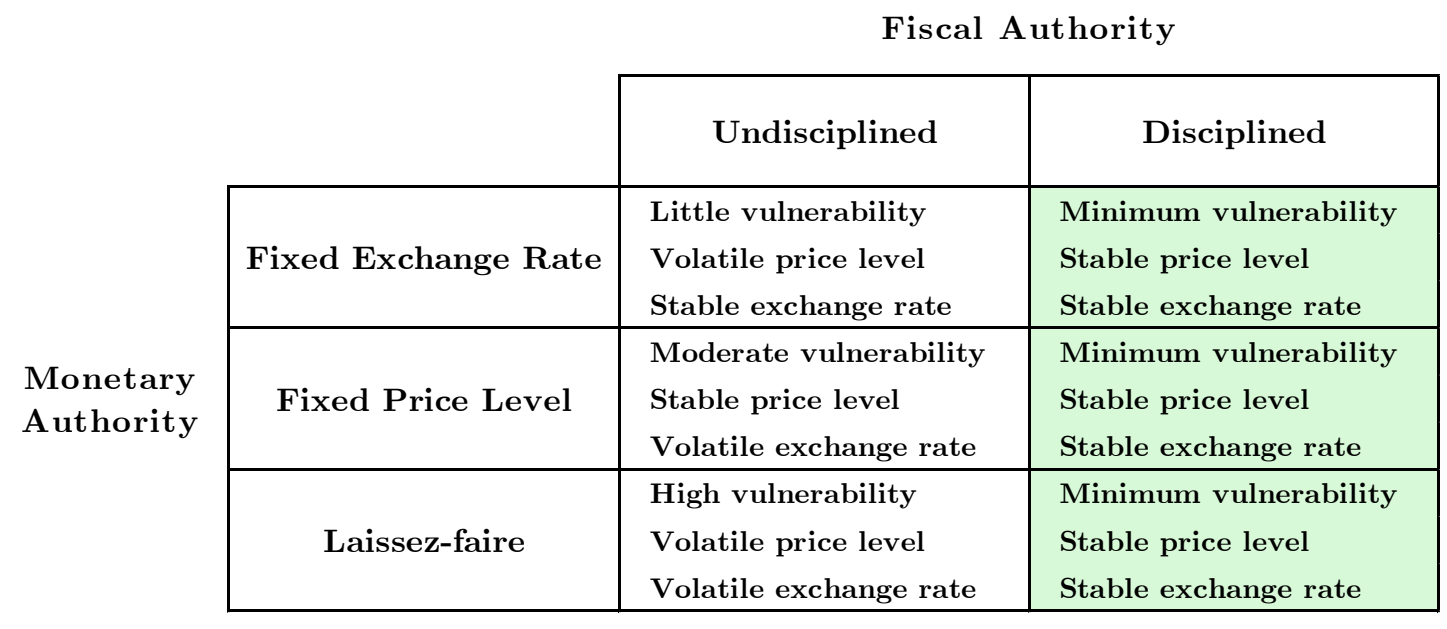

natural resource revenues (see Barnett and Ossowski, 2003). However a sharp increase/cut in spending during high/low natural resource revenues is commonplace among developing economies, which I treat as undisciplined.

In this paper I construct a general equilibrium model reflecting the main properties of a resource-exporting, developing, small economy to evaluate the effectiveness of different monetary regimes during shocks in revenues from natural resource exports. The model replicates the main macroeconomic developments in Azerbaijan, a post-Soviet transition economy which has been experiencing volatile and huge oil and gas revenues during the last decade. In line with Dutch Disease threats, the limitedness of oil reserves and volatile world oil prices make this country vulnerable to revenues from oil exports. To mitigate exchange rate appreciation, the Central Bank of Azerbaijan is intervening in the foreign exchange market. The simulation of the model reveals that such a policy response is effective in dealing with volatile and short-lived natural resource revenues. A similar situation has been observed in a number of natural resource exporting emerging countries, making the findings of this research applicable also for these countries. Moreover, the results from this paper can be applied for aid receiving countries due to similarities between aid and natural resource revenue inflows.

The remainder of the paper is organized as follows: The next section reviews 
the existing related literature on the topic. Section 3 describes the macroeconomic situation and monetary policy in Azerbaijan to support the relevance of the model presented in section 4 . The simulation and findings of the model are presented in section 5 and section 6 concludes.

\section{Literature Review}

Resource-rich economies have been widely studied. The empirical literature on the one hand finds a negative relationship between natural resource abundance and economic growth, and on the other hand tries to answer the question why resourcerich economies tend to grow slower (Sachs and Warner, 1995, 2001; Auty, 2001a; Gylfason et al., 1997; Cerny and Filer, 2007). The observed slower growth rate in natural resource exporting countries, also known as the resource curse, is mainly explained through the Dutch Disease concept. The Dutch Disease term was used for the first time to describe the decline of the tradable sector in the Netherlands driven by the discovery of large natural gas fields in 1960s. In general the Dutch Disease defines an economic situation in which all other traded sectors are crowded out by the one dominant tradable sector. Furthermore, the increased exports of the dominant sector create appreciation pressure on the domestic currency, which in turn harms the exports of other tradable goods.

The consolidated analysis of Dutch Disease was pioneered by Corden (1982, 1984, 1997). His archetypal economy includes three sectors: one non-tradable and two tradable sectors. In the benchmark case, a boom in one of the tradable sectors (termed as the booming sector) leads to exchange rate appreciation and the contraction of the other tradable sector (termed as the lagging sector). The resourcemovement and the spending effects are identified as two driving forces of Dutch Disease (Neary and Van Wijnbergen, 1986; Corden, 1982; Acosta et al., 2009).

Corden (1982) examines different protective policies, such as trade protection through tariffs and quotas, tax and subsidization and exchange rate protection. According to him, exchange rate protection through devaluation or preventing the appreciation of the exchange rate may seem attractive but this policy is not the first 
best response because this policy induces price increases and protects not only the lagging sector but also the booming sector, which is unnecessary. Such a policy is disruptive if it leads to non-optimal saving and accumulation of international reserves. Alternatively, a country can subsidize the lagging sector by taxes collected from the booming sector or apply tariffs or quantitative restrictions on imports. However, tough international rules against tax-subsidization and difficulties in the legislation of tariffs make exchange rate protection more favorable. Moreover, if a boom is due to the opening up of oil or gas reserves or a positive shock to world oil prices, then exchange rate protection can help moderate the effects of the shock. Corden claims that during investment and export booms a fixed exchange rate regime through foreign reserves accumulation and the sterilization of its monetary consequences can prevent real appreciation and insulate an economy from Dutch Disease.

Lartey (2008) studies the role of monetary policy in a small open economy facing a huge inflow of capital due to a negative shock to the price of imported investment. He finds that Dutch Disease in the form of a contracting manufacturing sector, rising prices of nontradables and real exchange rate appreciation occurs only under a fixed exchange rate regime and inactive monetary policy. However under a generalized Taylor rule where the interest rate is used to mitigate the deviations of GDP, inflation in nontradables, and the exchange rate from the steady state Dutch Disease never occurs. The paper mainly focuses on effective investment and on the reduction in the price of exported investment, which is different from the story of natural resource abundant developing countries.

Larsen (2004) points out a range of policy directives implemented by Norway through which Dutch Disease has successfully been avoided and revenues from oil extraction have been used to accelerate economic growth. The most important lesson is investing a significant part of revenues outside the economy and eliminating a possible wage differential between resource and other manufacturing sectors. Stevens (2003) claims that the resource "curse" can be turned into a "blessing" only through prudent fiscal and monetary policies, with the dominant role of the former policy. It is commonly accepted that the first best solution is the restriction of fiscal expansion 
and investing a significant part of the oil revenues outside the domestic economy, though there does not exist one rule for all cases, i.e., each country needs a specific approach (Barnett and Ossowski, 2003; Davis et al., 2003; Segura, 2006).

The formulation of the optimal spending strategy becomes difficult because resource abundance creates fertile ground for a rent seeking and predatory government (Auty, 2001b). Therefore, resource exporting economies tend to have poor spending strategies (Hermann, 2006). Implicit proof is that in oil exporting countries the economic cycle and fiscal spending move in the same direction as world oil prices (Husain et al., 2008; Aliyev, 2012). The behavior of a resource-rich economy becomes tricky if the government spends huge revenues from resource exports in the short run. In this case monetary policy faces a dilemma in choosing between the stabilization of inflation or the exchange rate. If the central bank chooses to target inflation, the exchange rate becomes unsteady; conversely if it chooses to target the exchange rate, inflation becomes uncontrollable. Because in most oil exporting emerging countries monetary authorities use the exchange rate as a nominal anchor (Calvo and Reinhart, 2000; Da Costa and Olivo, 2008; Setser, 2007), the central bank faces difficulties in controlling inflation. To maintain exchange rate stability the central bank increases the money supply, which leads to an increase in foreign exchange reserves. Under such combination of policies, the central bank's behavior may seem tempting (Corden, 1982) as it protects the domestic tradable sector through exchange rate protection and saves some part of natural resource revenues as its foreign reserves.

Uncertainty and easiness of foreign currency inflows makes the stories of aid receiving and natural resource abundant countries very similar. Therefore in studying natural resource-rich countries, one can benefit from the literature on countries experiencing a huge inflow of aid surges. Macroeconomic policies carry high importance in dealing with the negative effects of huge and volatile foreign aid inflows (Adam et al., 2009; Prati and Tressel, 2006). For instance Prati and Tressel (2006) show that the adverse effects of foreign aid, Dutch Disease and volatility can be mitigated through the accumulation or spending of international reserves. 
In the most relevant study Sosunov and Zamulin (2007) investigate an economy where all tradable sectors are completely compressed by the oil and gas sector. Their main finding is that the way the central bank of Russia responds to inflation and the real exchange rate through foreign exchange interventions is optimal. With such a policy the central bank of Russia accumulates international reserves and plays the role of a stabilization fund. There exist some shortcomings in Sosunov and Zasulin's analysis that can be improved. First, they do not consider a tradable sector other than the oil and gas production sector, which is very important in countries facing Dutch Disease. Second, in their study money is modeled on an ad hoc basis, i.e., money demand is simply determined by a consumption based quantity equation. Therefore in this cashless economy money serves as a numeraire and there is no explicit justification for agents to hold money (for a detailed discussion see Gali [2008] and Woodford [2003]).

Lama and Medina (2010) evaluate the role of nominal exchange rate stabilization in a small open economy affected by Dutch Disease. They find that preventing exchange rate appreciation mitigates contraction of tradable output. Lama and Medina also show that such a policy through exchange rate interventions is highly distortionary as it leads to the misallocation of resources and reduces welfare. In a very recent study Benkhodja (2011) analyses monetary policy and the Dutch Disease in a DSGE framework. He finds that a flexible exchange rate regime improves the social welfare and helps to avoid the Dutch Disease.

This review of the existing literature shows that there is no research that focuses on the unique role of exchange rate pegging through foreign exchange interventions and international reserve management in a natural resource abundant developing economy. Given underdeveloped financial markets and poor spending experiences of developing countries, such a policy may have exceptional benefits in response to volatile and limited windfall revenues. My research intends to shed a light on this aspect of monetary policy in a small, open economy in a DSGE framework. 


\section{Background: Azerbaijan}

To support the main idea of the paper I consider the example of Azerbaijan, an oil and gas rich, developing, small, open economy. This country possesses the macroeconomic setting described in this research, though there are dozens of other countries with a similar situation.

After the collapse of the Soviet Union, Azerbaijan regained independence in 1991, which brought new challenges arising from broken economic relations and a fragile economic and political system. The contract signed with western oil companies in 1994 started a new era of huge oil revenues. ${ }^{1}$ During the 2000s, economic growth has accelerated, mainly driven by oil and gas production. The domestic economy is heavily affected by massive windfall revenues, hence the share of the oil in GDP (Figure 2) and in total exports (around 95\% during 2007-2011) is extremely high.

In the meantime, oil financed fiscal expansion creates appreciation pressure on the domestic currency. To prevent exchange rate appreciation the Central Bank of Azerbaijan increases the money supply which in turn raises its international reserves. (Figure 3). The recent world financial crisis gives an interesting insight into the mechanism of stabilization. The decline in oil and gas revenues was accompanied with a fall in international reserves of the central bank and a constant money supply. This means that during low oil revenue period the Central of Azerbaijan was using its international reserves as a buffer. Because of this policy we observe a nearly constant exchange rate for all periods and accelerated inflation before the crisis and low inflation during the crisis (Figure 4).

Given these numbers one can infer that in Figure 1, the case of Azerbaijan is situated at the intersection of "undisciplined" and "fixed exchange rate" strategies, where the government chooses to spend petrodollars and the central bank partially neutralizes the impact of these dollars by foreign exchange interventions. During high oil revenues the outcomes of this combination of policies are a fixed exchange

\footnotetext{
${ }^{1}$ The earliest era started in the 19th century when Azerbaijan was on the frontier in the world's oil industry and by the beginning of the 20th century more than half of the world's oil was produced here.
} 
Figure 2: Structure of real GDP (bln. USD)

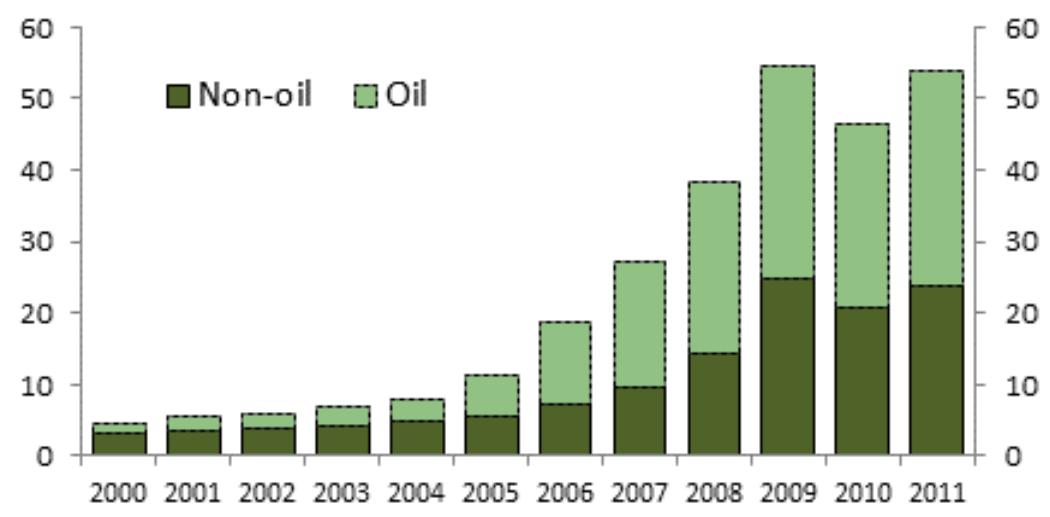

Source: The Central Bank of Azerbaijan, The State Statistical Committee of Azerbaijan

Figure 3: Selected macroeconomic variables (bln. USD)

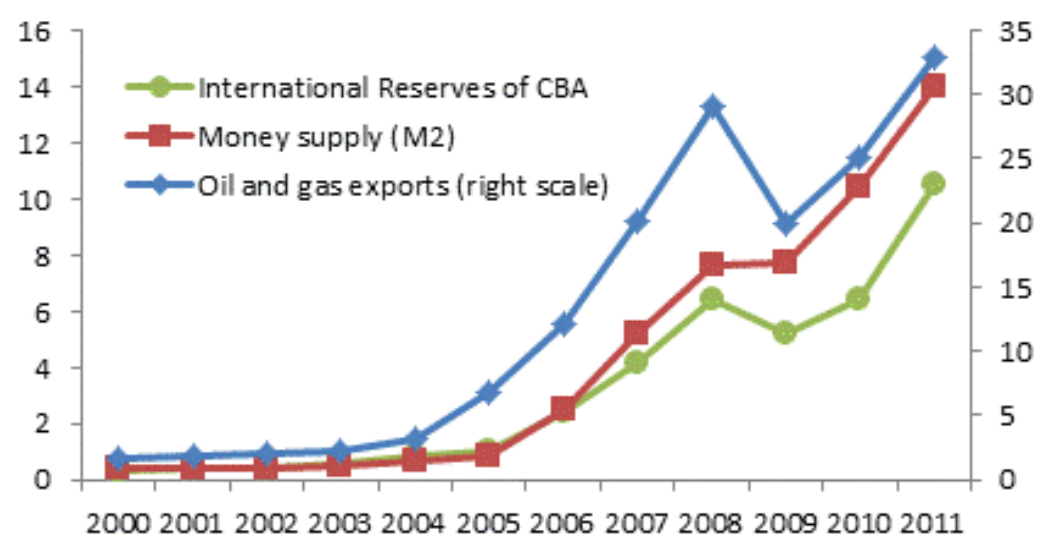

Source: The Central Bank of Azerbaijan

Figure 4: Inflation (CPI)

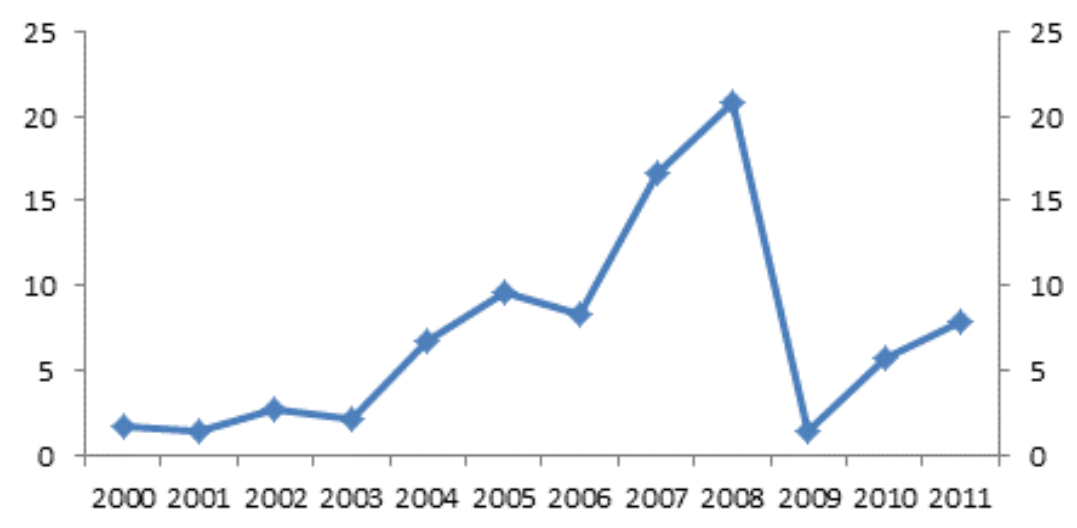

Source: The Central Bank of Azerbaijan, The State Statistical Committee of Azerbaijan 
rate and accelerated inflation. If the Central Bank of Azerbaijan would choose laissez faire or price level targeting, then the exchange rate would appreciate, harming the already fragile domestic tradable sector and more oil revenues would be spent in the short run. Therefore the current policy followed by the Central Bank of Azerbaijan is efficient in the sense that besides exchange rate pegging it helps to achieve two important goals. First, such a policy stabilizes the economy in face of volatile oil revenues by using international reserves as a buffer. Second, saving some part of oil revenues abroad implicitly softens the negative effects of Dutch Disease. The results obtained from the theoretical model presented in the next section support this idea.

These findings in some sense coincide with the IMF's policy recommendations for Azerbaijan. After 2003, the IMF changed its agreement about the appropriateness of an exchange rate anchor, which for a long period served to achieve macroeconomic stability and insisted in allowing nominal appreciation and maintaining lower inflation later on. Only in 2010 it clearly supported a U.S. dollar peg as an appropriate regime in the short term and more flexible in the medium term (IMF Country Reports).

\section{The Model}

I construct a dynamic general equilibrium model of a resource-rich, small, open, two sector economy. The economy consists of four key agents: households, firms, fiscal and monetary authorities. Besides the fiscal authority the monetary authority also has a peculiar independence in saving some part of these revenues in the form of its international reserves through foreign exchange interventions. The domestic economy produces two types of consumption goods: non-tradables and tradable manufactured goods. There is an international market of tradable goods with unlimited demand and supply with constant world prices. Households cannot save/borrow to smooth their consumption across periods. This assumption is made to reflect the situation observed in most underdeveloped natural resource rich countries where a huge part of natural resource revenues is spent on non-durable consumption goods in the short run. 


\subsection{Households}

The economy is populated by infinitely many identical households of measure unity. The representative household is endowed with one unit of time and transfer from the government, $\tau_{t} F_{t}$, each period. Here $\tau_{t}$ is a share of natural resource revenues transferred to households by the fiscal authority. $F_{t}$ represents total natural resource endowment meaning that fluctuations in world prices of exported natural resource or changes in natural resource exports has a direct impact on it. The time endowment is split between leisure and work. The representative household enters each period with a nominal money balance from the previous period $\left(M_{t-1}\right)$, and receives profit from the production sector $\left(\Pi_{t}\right)$, interest on fixed capital $(K)$, and wages on supplied labor $(L)$.

The household has preferences over consumption goods $\left(C_{t}\right)$, leisure $\left(1-L_{t}\right)$, and real money balances $\left(\frac{M t}{P_{t}}\right)$. The representative household seeks to solve the following maximization problem:

$$
\underset{\left\{C_{t}^{M}, C_{t}^{N}, M_{t}, L_{t}\right\}}{\operatorname{Max}} E_{0} \sum_{t=0}^{\infty} \beta^{t}\left[\zeta \operatorname{Ln}\left(C_{t}\right)+\chi \operatorname{Ln}\left(\frac{M_{t}}{P_{t}}\right)+\psi \operatorname{Ln}\left(1-L_{t}\right)\right],
$$

subject to budget constraint

$$
M_{t-1}+e_{t} \tau_{t} F_{t}+W_{t} L_{t}+R_{t} K_{t}+\Pi_{t}=M_{t}+P_{t}^{M} C_{t}^{M}+P_{t}^{N} C_{t}^{N} .
$$

Here $\beta$ is the discount factor, $C_{t}$ is the aggregate consumption index consisting of the consumption of manufactured goods $C_{t}^{M}$ and non-tradable goods $C_{t}^{N}$, defined by $C_{t}=\frac{\left(C_{t}^{M}\right)^{\theta}\left(C_{t}^{N}\right)^{1-\theta}}{\theta^{\theta}(1-\theta)^{1-\theta}}, e_{t}$ is the nominal exchange rate in the units of domestic currency per unit of foreign currency, $W_{t}$ is the nominal wage, $R_{t}$ is the nominal interest rate, $P_{t}^{N}$ is the price of domestic non-tradable goods and $\zeta, \chi, \psi>0$. The price of foreign tradable goods $\left(P_{t}^{M^{*}}\right)$ is given exogenously, hence I normalize it to one. Therefore the price of tradable goods in the domestic currency $\left(P_{t}^{M}\right)$ equals the nominal exchange rate: $P_{t}^{M}=e_{t} P_{t}^{M^{*}}=e_{t}$. Given the structure of the consumption aggregate, the consumption based price index is given by ${ }^{1} P_{t}=\left(P_{t}^{M}\right)^{\theta}\left(P_{t}^{N}\right)^{1-\theta}$.

\footnotetext{
${ }^{1}$ The aggregate price index is defined as a minimum expenditure price required to purchase one unit of composite real consumption. For the derivation see Appendix 2.
} 
Using the first order conditions of the household's maximization, I get the following equations: ${ }^{2}$

$$
\begin{gathered}
\frac{P_{t}^{M} C_{t}^{M}}{P_{t}^{N} C_{t}^{N}}=\frac{\theta}{1-\theta} ; \\
\frac{\chi}{M_{t}}=\frac{\zeta}{P_{t} C_{t}}-\beta \frac{\zeta}{P_{t+1} C_{t+1}} ; \\
\frac{\psi}{\zeta}=\frac{W_{t}\left(1-L_{t}\right)}{P_{t} C_{t}} .
\end{gathered}
$$

Equation (2) shows that the ratio of the value of the two types of consumption goods is constant and depends on the shares of different consumption goods in aggregate consumption. With equal shares the value of the consumption of manufactured and tradable goods should be the same. Equation (3) can be written as

$$
\frac{\zeta}{P_{t} C_{t}}=\chi E_{t} \sum_{j=0}^{\infty} \beta^{j} \frac{1}{M_{t+j}} \text {. }
$$

This equation relates the current value of consumption to the expected future growth rate of the money supply. Equation (4) expresses the relationship between the household's choice over consumption and leisure. Precisely, it relates the ratio between the nominal value of aggregate consumption and leisure to the ratio of the coefficient of consumption and leisure in the household's utility function.

\subsection{Firms}

There are two production sectors in the domestic economy, tradable and nontradable, and a continuum of identical firms in each sector. I assume Cobb-Douglas technology in both sectors with different capital/labor intensities and total factor productivities. The factors of production are mobile between the sectors, hence wages and the interest rates are equal in both sectors. I fix aggregate capital at a constant level $\bar{K}$. Therefore $\bar{K}=K_{t}^{M}+K_{t}^{N}$. A representative firm solves the profit maximization problem in the tradable sector,

\footnotetext{
${ }^{2}$ The derivations are given in Appendix 1.
} 


$$
\underset{\left\{K_{t}^{M}, L_{t}^{M}\right\}}{\operatorname{Max}}\left\{P_{t}^{M} Y_{t}^{M}-R_{t} K_{t}^{M}-W_{t} L_{t}^{M}\right\},
$$

and in the non-tradable sector,

$$
\underset{\left\{K_{t}^{N}, L_{t}^{N}\right\}}{\operatorname{Max}}\left\{P_{t}^{N} Y_{t}^{N}-R_{t} K_{t}^{N}-W_{t} L_{t}^{N}\right\}
$$

Production functions are given by $Y_{t}^{M}=A\left(K_{t}^{M}\right)^{\alpha}\left(L_{t}^{M}\right)^{1-\alpha}$ and $Y_{t}^{N}=B\left(K_{t}^{N}\right)^{\gamma}\left(L_{t}^{N}\right)^{1-\gamma}$, where $\alpha$ and $\gamma$ are capital shares, and $A$ and $B$ are total factor productivities in the tradable and non-tradable sectors, respectively. From the first order conditions of these problems I derive the following equation: ${ }^{3}$

$$
\left(\frac{\alpha}{\gamma}\right)^{\alpha}\left(\frac{1-\gamma}{1-\alpha}\right)^{\alpha-1}\left(\frac{K_{t}^{N}}{L_{t}^{N}}\right)^{\alpha-\gamma}=\frac{P_{t}^{N}}{P_{t}^{M}} .
$$

This equation means that if capital intensity in the tradable sector is higher than capital intensity in the non-tradable sector, then any change in the price ratio leads to a proportional change in the capital/labor ratio.

\subsection{Fiscal Authority}

Each period the fiscal authority receives natural resource revenues and decides what share of these revenues to transfer to households. For the sake of simplicity I assume that the fiscal authority faces two possible choices: (i) it is either disciplined $\left(\tau_{t} \neq 1\right)$; or (ii) it behaves in an undisciplined way $\left(\tau_{t}=1\right)$. Under fiscal discipline, the fiscal authority chooses values for $\tau_{t}$ such that households' endowment does not deviate from the long run average value of natural resource revenues. This implies that there is no effect of temporary changes in natural resource revenues on the domestic economy or in other words permanent income level is maintained. In contrast under undisciplined fiscal policy any shock to the natural resource is reflected in the household's natural resource endowment. I assume that the fiscal authority saves natural resource revenues outside the domestic economy without interest accumulation in a special welfare fund. The accumulation of the resources in this fund is given by

\footnotetext{
${ }^{3}$ See Appendix 3 for the derivations.
} 
$\Phi_{t}=\Phi_{t-1}+\left(1-\tau_{t}\right) F_{t}$.

As it is discussed above disciplined fiscal policy does not necessarily imply zero transfers to households and accumulation of all revenue from natural resource exports. Therefore in the model instead of $\tau_{t}=0$, (i.e., government saves all the revenue), I assume $\tau_{t} \neq 1$, which implies that the disciplined fiscal authority constantly changes its control variable in order to maintain transfers at the permanent level.

\subsection{Monetary Authority}

The central bank chooses between one of three monetary regimes: (i) exchange rate targeting, (ii) price level targeting, and (iii) laissez faire, where the central bank fixes the money supply. The assumption of the three pure regimes may seem unrealistic, however, pegging the exchange rate and inflation targeting are two alternative policies usually considered by central bankers. Here I also consider a laissez faire policy or fixed money supply to capture the benchmark case where the central bank is inactive. Depending on the implemented policy rule, one of the variables, $e_{t}, P_{t}$, or $M_{t}$ is fixed.

The central bank uses foreign exchange interventions to control the money supply. It can sell/buy domestic currency $\left(M_{t}\right)$, and buy/sell some share $\left(\mu_{t}\right)$ of foreign exchange inflows $\left(F_{t}\right)$ in the foreign exchange market. This policy determines the path of international reserves $\left(S_{t}\right)$ denominated in the foreign currency and held outside the domestic economy:

$$
S_{t}=S_{t-1}+\mu_{t} F_{t}
$$

An increase in the money supply is given by the following equation:

$$
\Delta M_{t}=e_{t} \mu_{t} F_{t} .
$$

The foreign exchange interventions enable the monetary authority to play a crucial role in the allocation of resources in the economy. By increasing/decreasing the money supply, the central bank uses inflation tax and controls how much natural resource revenues are spent and how much are saved as international reserves.

Here I do not make any assumption about the interest income on accumulated 
reserves, neither of the fiscal authority, nor of the central bank. In the long run the equilibrium value of foreign reserves and consequently interest accumulation is zero. Introducing interest income does not have any qualitative impact in the long run, though one can use interest for estimating the optimal spending/saving strategy in the short run to get more precise quantitative results. Given heterogeneous reserve accumulation under different regimes, extra investment income would strengthen the position of a regime with higher accumulation from the welfare perspective.

\subsection{Equilibrium}

Now the characterization of the environment is completed, so I can define the equilibrium. Given the sequence of natural resource revenues $\left\{F_{t}\right\}_{t=0}^{\infty}$ there is an equilibrium where the sequence of household's choice of $\left\{C_{t}^{M}\right\}_{t=0}^{\infty},\left\{C_{t}^{N}\right\}_{t=0}^{\infty},\left\{M_{t}\right\}_{t=0}^{\infty},\left\{L_{t}\right\}_{t=0}^{\infty}$, the firm's choice of $\left\{K_{t}^{M}\right\}_{t=0}^{\infty},\left\{K_{t}^{N}\right\}_{t=0}^{\infty},\left\{L_{t}^{M}\right\}_{t=0}^{\infty},\left\{L_{t}^{N}\right\}_{t=0}^{\infty}$, the fiscal authority's choice of $\left\{\tau_{t}\right\}_{t=0}^{\infty}$, the central bank's control variable $\left\{\mu_{t}\right\}_{t=0}^{\infty}$, prices $\left\{P_{t}^{M}\right\}_{t=0}^{\infty},\left\{P_{t}^{N}\right\}_{t=0}^{\infty}$, exchange rate $\left\{e_{t}\right\}_{t=0}^{\infty}$, interest rate $\left\{R_{t}\right\}_{t=0}^{\infty}$, and wage rate $\left\{W_{t}\right\}_{t=0}^{\infty}$ such that

(i) the household's utility maximization problem (1) is solved,

(ii) the firms' profit maximization problems (5) and (6) are solved,

(iii) the market clearing holds

- in the labor market: $\left(L_{t}\right)^{s}=\left(L_{t}^{M}\right)^{d}+\left(L_{t}^{N}\right)^{d}$

- in the capital market: $\bar{K}=\left(K_{t}^{M}\right)^{d}+\left(K_{t}^{N}\right)^{d}$

- in the tradable goods market: $C_{t}^{M}=Y_{t}^{M}+\left(\tau_{t}-\mu_{t}\right) F_{t}$

- in the non-tradable goods market: $C_{t}^{N}=Y_{t}^{N}$

- in the money market: $M_{t}-M_{t-1}=e_{t} \mu_{t} F_{t}$.

The market clearing condition in the tradable goods market means that households' demand for tradable goods can be either met by the domestic production of tradables or by import in exchange for foreign revenues from resource exports. Here $\mu_{t}$ may result in negative values meaning that spending on imported goods 
exceeds foreign revenues. This happens through a decrease in the money supply and correspondingly the depletion of international reserves.

\section{Calibration}

To solve the model numerically I fix the model parameters consistent with the values used in the economic literature. I assume that households assign a lower share (0.4) to manufactured goods in their utility function. The capital share in the manufactured goods production sector is higher than the capital share in the non-tradable goods production sector. This assumption comes from the fact that the non-tradable sector mainly consists of a labor intensive service sector opposed to the more capital intensive tradable sector, which mainly produces manufactured goods. Assuming a considerable low capital share in the non-tradable sector has only a quantitative impact and enables visualization of the differences between monetary regimes. In the initial steady state I normalize the total production (non-resource output denominated in foreign currency $Y)$, prices $\left(P, P^{M}\right.$, and $\left.P^{N}\right)$, exchange rate $(e)$ and money supply $(M)$ to unity. This normalization enables tracking the changes in model variables as a percentage deviation from the base value. The value of fixed capital stock is taken from Koeda and Kramarenkos' (2008) estimate for Azerbaijan. I assume that the household spends $3 / 5$ of its time for work and $2 / 5$ for leisure. The list of all the simulation parameters used in the simulations is given in Table $1 .^{4}$ After the simulations I additionally test the robustness of the results to changes in parameters.

\subsection{Simulation Results}

In this section I describe the simulation of the model and the results computed from this simulation. The structural form of the model is shown in Appendix 4. I use the MATLAB software package and the Dynare toolbox in all my computations.

\footnotetext{
${ }^{4}$ The structural form of the model is given in Appendix 4 .
} 


\section{Table 1: Parameters used in calibration}

\begin{tabular}{lll}
\hline$\beta$ & discount factor & 0.99 \\
$\zeta$ & coefficient on consumtion in utility & 1.15 \\
X & coefficient on money in utility & 0.01 \\
$\Psi$ & coefficient on leisure in utility & 1 \\
$\theta$ & share of manufactured goods in aggregate consumption & 0.4 \\
$\alpha$ & capital share in the tradable sector & 0.4 \\
Y & capital share in the non-tradable sector & 0.1 \\
A & total factor productivity in tradable sector & 1.13 \\
B & total factor productivity in non-tradable sector & 2.16 \\
K & capital stock & 1.66 \\
F & long run average of resource revenues in the AR model & 0.5 \\
$\rho$ & parameter of the AR model & 0.9 \\
$\sigma$ & standard deviation of shocks in AR model & 0.0001 \\
\hline
\end{tabular}

First I consider the effects of a permanent positive shock on the revenues from natural resource exports. Then I analyze the case where natural resource revenues are assumed to be stochastic. Stochasticity of natural resource revenues can be due to volatility in the world prices of the exported natural resource or the uncertainty of existing resources or future production capacity. The deterministic case with a permanent positive shock is studied because of two reasons. First, it enables me to illustrate the effects of Dutch Disease in detail. Secondly, it explains the intuition behind the findings from the case where natural resource revenues are stochastic.

In all cases under the disciplined fiscal policy natural resource revenues have no impact because of full isolation of the economy from the shocks. Hence fiscal discipline equates the situation with volatile natural resource revenues to a one where natural resource revenues do not fluctuate. Naturally in this framework monetary policy does not play any role. Therefore I consider only the case with an undisciplined fiscal policy and compare the results under different monetary regimes with a benchmark case where the fiscal authority is disciplined. 


\subsubsection{Consequences of a permanent positive shock on natural resource revenues}

For now let's assume that revenues from natural resource exports jump up permanently. Perhaps an increase in foreign revenues that lasts forever is not a realistic assumption, but such a formulation enables us to observe the effects of Dutch Disease and the role of monetary policy in the reallocation process during the transition period to a new steady state. I assume that in the beginning there is no revenue from natural resource exports and the economy is in a steady state. Suddenly in period $t=5$ foreign resource revenues jump to a level where the domestic economy produces almost only tradable goods and the tradable sector is squeezed out. This assumption is made to reflect a situation where the economy suddenly experiences a huge inflow of windfall revenues due to the discovery of natural resource fields.

The first finding from this analysis is the symptoms of Dutch Disease observed under all monetary regimes. Hence in general the steady-state values of the real macroeconomic variables do not differ under various monetary regimes except foreign international reserves (Table 2). By comparing prior and posterior steady state levels, we can draw several conclusions about the effects of Dutch Disease. The natural resource sector does not use labor and capital in the model, and consequently the resource movement effect is ruled out. Therefore, the wealth effect is the only driving force of the changes. ${ }^{5}$ Increased income due to a permanent positive shock on foreign revenues increases aggregate demand and price level, which implies real appreciation. The excess demand for the tradables and non tradables is satisfied through imports and domestic production, respectively. Therefore factors of production move from the tradable sector towards the nontradable sector. The nominal wage rate rises and the nominal interest rate declines. Hence Dutch Disease is observed in the form of real appreciation, contraction of the domestic tradable sector's production and an increase of nontradable sector output no matter which monetary regime is implemented.

\footnotetext{
${ }^{5}$ See Corden (1982) for a detailed analysis of wealth and resource movement effects in a three sector economy.
} 
Table 2: Prior and posterior steady-state results

\begin{tabular}{|c|c|c|c|c|c|}
\hline & & \multirow{2}{*}{$\begin{array}{c}\text { Prior } \\
\text { Steady } \\
\text { State }\end{array}$} & \multicolumn{3}{|c|}{ Posterior Steady State } \\
\hline & & & $\begin{array}{c}\text { Fixed } \\
\text { Exchange } \\
\text { Rate }\end{array}$ & $\begin{array}{l}\text { Fixed } \\
\text { Price } \\
\text { Level }\end{array}$ & $\begin{array}{l}\text { Laissez- } \\
\text { faire }\end{array}$ \\
\hline $\mathbf{F}$ & natural resource revenues (in foreign currency) & 0.0 & 0.65 & 0.65 & 0.65 \\
\hline C & aggregate consumption & 1.00 & 1.42 & 1.42 & 1.42 \\
\hline $\mathrm{Cm}$ & consumption of tradables & 0.40 & 0.69 & 0.69 & 0.69 \\
\hline $\mathrm{Cn}$ & consumption of non-tradables & 0.60 & 0.75 & 0.75 & 0.75 \\
\hline $\mathbf{Y}$ & aggregate output (in foreign currency) & 1.00 & 1.07 & 1.07 & 1.07 \\
\hline Ym & output in tradable sector (in foreign currency) & 0.40 & 0.04 & 0.04 & 0.04 \\
\hline Yn & output in non-tradable sector (in foreign currency) & 0.60 & 1.03 & 1.03 & 1.03 \\
\hline e & nominal exchange rate & 1.00 & 1.00 & 0.83 & 0.58 \\
\hline $\mathbf{P}$ & aggregate price level & 1.00 & 1.21 & 1.00 & 0.70 \\
\hline Pn & price of non-tradables & 1.00 & 1.37 & 1.13 & 0.80 \\
\hline Pm & price of tradables & 1.00 & 1.00 & 0.83 & 0.58 \\
\hline $\mathbf{L}$ & aggregate labor & 0.40 & 0.32 & 0.32 & 0.32 \\
\hline Lm & labour in tradable sector & 0.12 & 0.01 & 0.01 & 0.01 \\
\hline Ln & labour in non-tradable sector & 0.28 & 0.31 & 0.31 & 0.31 \\
\hline $\mathbf{K m}$ & capital in tradable sector & 1.207 & 0.208 & 0.208 & 0.208 \\
\hline Kn & capital in non-tradable sector & 0.453 & 1.452 & 1.452 & 1.452 \\
\hline $\mathbf{W}$ & nominal wage rate & 1.95 & 2.96 & 2.45 & 1.72 \\
\hline $\mathbf{R}$ & nominal interest rate & 0.13 & 0.07 & 0.06 & 0.04 \\
\hline M & money supply & 1.00 & 1.72 & 1.42 & 1.00 \\
\hline IR & international reserves (in foreign currency) & 0.0 & 0.7 & 0.5 & 0.0 \\
\hline
\end{tabular}

The second interesting observation is heterogeneous accumulation of international reserves and the growth in the money supply across different monetary regimes (Figure 5) during the transition to a new steady-state. As we see under a fixed exchange rate and price level targeting regimes, there is an accumulation of international reserves contrary to the laissez-faire policy, where accumulation does not occur. We also observe higher accumulation of international reserves under exchange rate targeting compared to price level targeting. These differences are due to the fact that the highest intensity of foreign exchange interventions happens under a fixed exchange rate regime. Under price level targeting such actions are less intensive and under laissez faire there is no intervention. Because of these differences in the accumulation of international reserves the consumption of tradables is the highest under laissez faire, medium under price level targeting and the smallest under a fixed exchange regime. Therefore a fixed exchange rate regime brings about lower exchange rate appreciation and higher production of tradable goods during the transition period. To generalize all these observations, we can conclude that during high natural resource revenues a fixed exchange rate regime outperforms other regimes 
by saving some part of windfall revenues for future generations and by weakening the symptoms of Dutch Disease in the short run. My further analyze with stochastic natural resource revenues is mainly based on these findings.

Figure 5: Transition to the new steady state
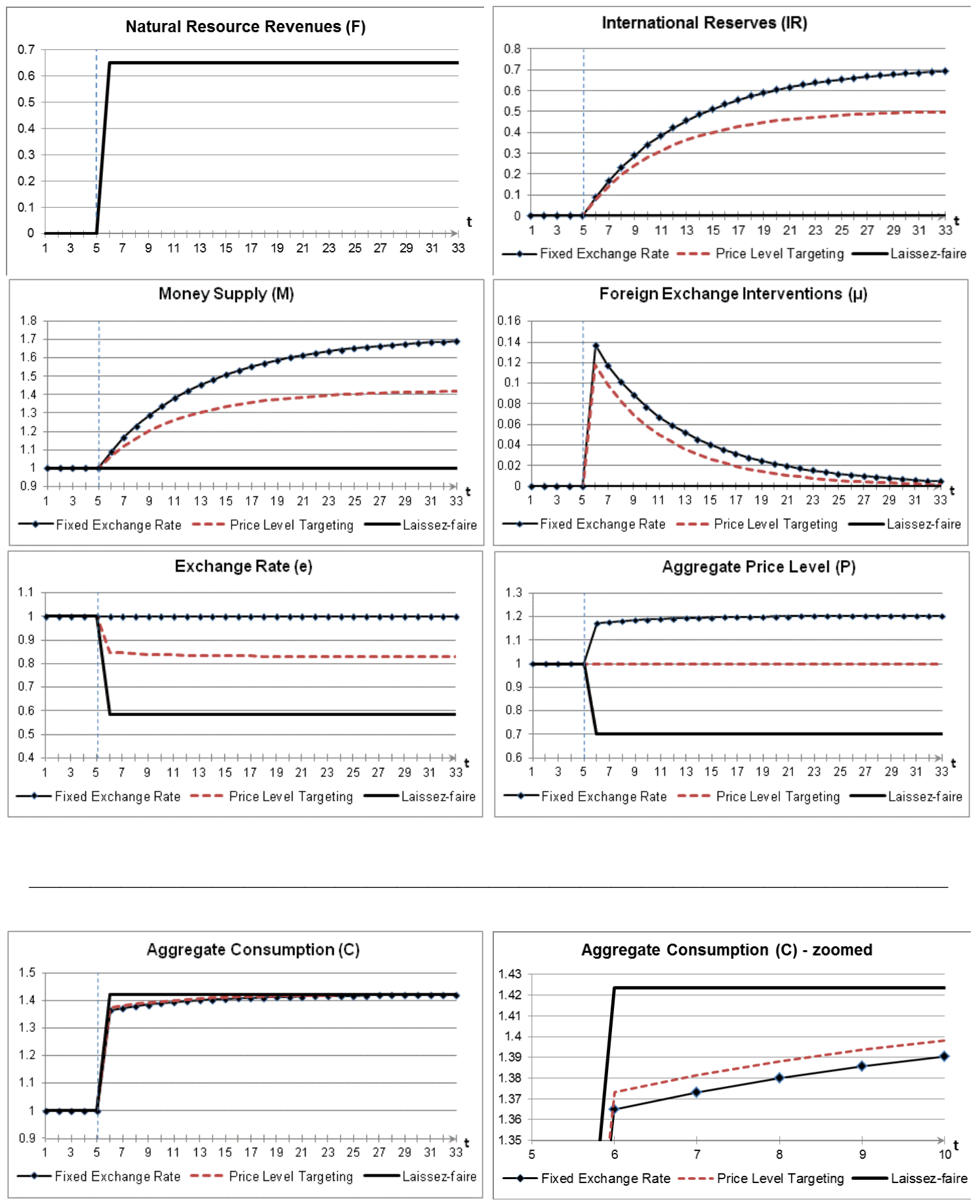

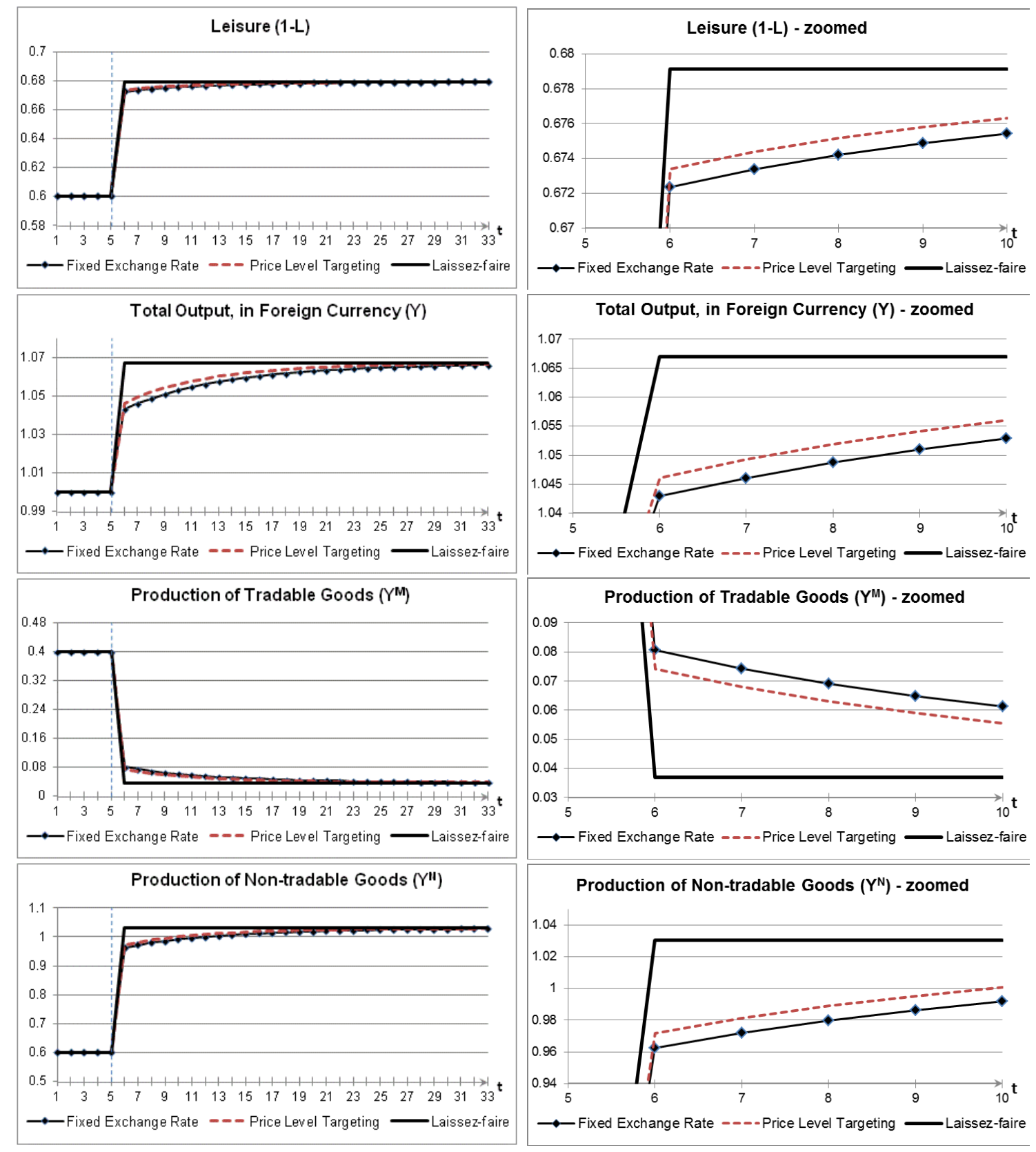

$\longrightarrow$ - Fixed Exchange Rate - - -- Price Level Targeting — Laissez-faire

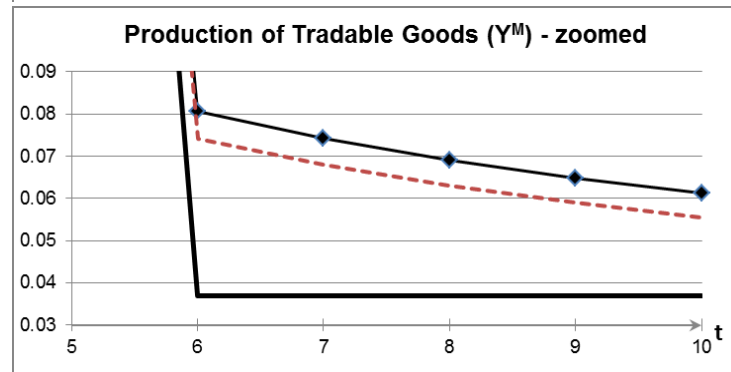

$\longrightarrow$ - Fixed Exchange Rate ----Price Level Targeting — Laissez-faire

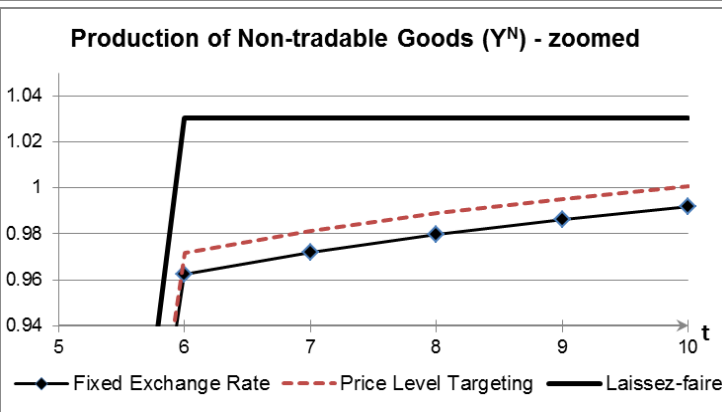

\subsubsection{Stochastic revenues from natural resource exports}

Now I can turn to a more realistic assumption where foreign revenue from natural resource exports is stochastic. Following the literature I assume that revenue from natural resource exports is determined by an $\mathrm{AR}(1)$ process defined as

$$
F_{t+1}=\rho F_{t}+(1-\rho) \bar{F}+\epsilon_{t} .
$$

Here $0<\rho<1$ and $\epsilon \sim N(0, \sigma)$. The long run average of foreign resource revenues $(\bar{F})$ is taken such that the economy produces mostly non-tradable goods and 
imports the main part of tradable goods from abroad. This assumption reflects the macroeconomic situation in developing economies heavily affected by the abundance of natural resources.

\section{Table 3: Simulation results}

\begin{tabular}{|c|c|c|c|c|}
\hline & \multirow{2}{*}{$\begin{array}{l}\text { Disciplined } \\
\text { Fiscal Policy }\end{array}$} & \multicolumn{3}{|c|}{ Undisciplined Fiscal Policy } \\
\hline & & $\begin{array}{c}\text { Fixed Exchange } \\
\text { Rate }\end{array}$ & $\begin{array}{c}\text { Fixed Price } \\
\text { Level }\end{array}$ & Laissez Faire \\
\hline \multicolumn{5}{|l|}{ Variation } \\
\hline aggregate consumption & 0.0000 & 0.0094 & 0.0100 & 0.0120 \\
\hline leisure & 0.0000 & 0.0029 & 0.0031 & 0.0037 \\
\hline exchange rate & 0.0000 & 0.0000 & 0.0056 & 0.0188 \\
\hline price level & 0.0000 & 0.0053 & 0.0000 & 0.0120 \\
\hline money supply & 0.0000 & 0.0798 & 0.0594 & 0.0000 \\
\hline Welfare cost of fluctuations, \% & $0.000 \%$ & $0.011 \%$ & $0.013 \%$ & $0.016 \%$ \\
\hline Total welfare & -4.4682 & -4.4806 & -4.4830 & -4.4866 \\
\hline \multicolumn{5}{|l|}{ Aggregate loss } \\
\hline$\lambda=0$ & 0.0000 & 0.0001 & 0.0000 & 0.0014 \\
\hline$\lambda=1$ & 0.0000 & 0.0010 & 0.0010 & 0.0028 \\
\hline$\lambda=2$ & 0.0000 & 0.0019 & 0.0020 & 0.0043 \\
\hline
\end{tabular}

The results from the simulation of the model under different monetary regimes are summarized in Table 3. As we see, a fixed exchange rate regime outperforms other regimes by delivering the smallest volatility in aggregate consumption and leisure. We observe higher volatility of money under a fixed exchange rate regime compared to other regimes. This happens because in order to fix the exchange rate, the central bank uses foreign exchange interventions more intensively to absorb the effects of shocks on foreign revenues. In particular during high natural resource revenues the central bank increases the money supply and accumulates its international reserves, and during low or zero foreign revenues it decreases the money supply by foreign exchange purchases that decrease its international reserves. A laissez-fare regime loses to other regimes by yielding considerably higher volatility in consumption as there is no use of foreign exchange interventions and international reserves. All these differences in volatilities can be visually seen in Figure 6. 
Figure 6: Fluctuations in some variables under different monetary regimes

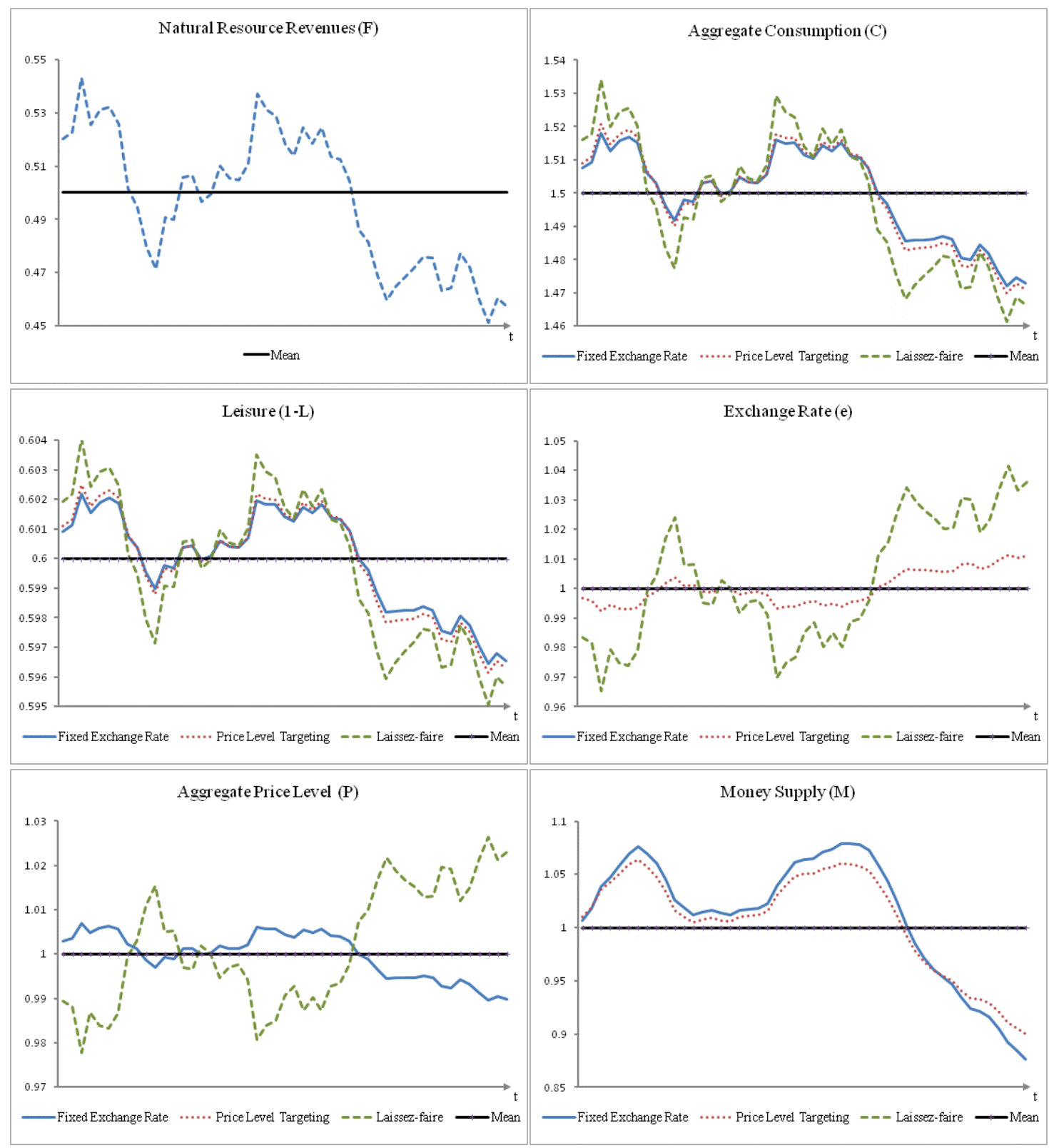

Different volatilities under different monetary regimes can be compared through the welfare cost of the business cycle. I use Lucas' (1987) approach to estimate the welfare cost of the business cycle:

$$
E_{0} \sum_{t=0}^{\infty} \beta^{t} U\left[\bar{C}, \frac{\bar{M}}{\bar{P}}, 1-\bar{L}\right]-E_{0} \sum_{t=0}^{\infty} \beta^{t} U\left[C_{t}(1+\eta), \frac{M_{t}}{P_{t}}, 1-L_{t}\right]=0
$$


where $\eta$ is the cost of fluctuations. The welfare cost of the business cycle denotes the percentage of increase in consumption needed each period to make the representative household indifferent between volatility and stability. The estimated values of $\eta$ (Table 3$)^{6}$ shows that the representative household living in the economy with a fixed exchange rate, price level targeting, and laissez faire will require a $0.011 \%, 0.013 \%$ and a $0.016 \%$ increase in consumption, respectively, to be indifferent between a current regime economy and an economy with no volatility, i.e., an economy with disciplined fiscal authority. These numbers tell us that if fiscal indiscipline is inevitable, then it is less costly to live in an economy with a fixed exchange rate regime compared to other monetary regimes.

As expected in terms of total welfare $\left(E_{0}\left[\sum_{t=0}^{\infty} \beta^{t} U\left(C_{t}, \frac{M_{t}}{P_{t}}, 1-L_{t}\right)\right]\right)$, the first best outcome is achieved when the fiscal authority is disciplined. If the fiscal authority is undisciplined, then a fixed exchange rate regime holds its second best position by delivering the highest total welfare (Table 3).

Alternatively, we can evaluate the role of monetary policy by specifying the preferences of the central bank. Following the standard specification I assume that the central bank's objective is to minimize the expected value of the following quadratic loss function (See Walsh, 2003):

$$
V_{t}=\frac{1}{2}\left[\lambda\left(Y_{t}-Y_{n}\right)^{2}+\left(\pi_{t}-\pi^{*}\right)^{2}\right] .
$$

Here $Y_{t}$ is the total output at period t denominated in foreign currency, $Y_{n}$ is its natural rate, $\pi_{t}$ is the inflation rate at period $\mathrm{t}, \pi^{*}$ is the long run inflation target, and $\lambda$ is the weight that the central bank assigns on output deviations relative to inflation stabilization. I assume that the central bank desires to stabilize output around $Y_{n}$, and inflation around zero $\left(\pi^{*}=0\right)$.

A minimum value of the expected aggregate loss $\left(E_{0}\left[\sum_{t=0}^{\infty} \beta^{t} V_{t}\right]\right)$ is achieved when fiscal authority is disciplined regardless of the implemented monetary regime (Table 3). Under undisciplined fiscal policy the parameter $\lambda$ plays a key role. Zero weight on output gap stabilization $(\lambda=0)$ implies strict inflation targeting (Svensson 1997), and the fixed price level obviously wins over all other regimes by delivering the same

\footnotetext{
${ }^{6}$ For the derivation of the $\eta$, see Appendix 5 .
} 
outcome as disciplined fiscal policy. If the central bank assigns equal shares to the output gap and inflation stabilization $(\lambda=1)$, then fixed exchange rate and fixed price level regimes bring about the same loss while a laissez-faire regime still falls behind. With higher weight on output gap stabilization $(\lambda=2)$, a fixed exchange rate regime outperforms other regimes. The varying outcomes under the different central bank's preferences are the result of the diversity in natures: a fixed price level regime implicitly targets inflation, while a fixed exchange rate regime stabilizes the real sector as well, and a laissez faire regime has no stabilization power.

All these comparisons provide the rationale why and how a fixed exchange rate regime may be an effective tool in the allocation of huge and volatile natural resource revenues in developing economies.

\subsection{Robustness test}

In this section I test the robustness of the previous results to changes in the parameters used in calibration. In the basic specification to normalize the variables of interest, I assigned peculiar but not very different from conventional values for the parameters in the utility block. A priori we can identify that all the parameters affect only the steady-state levels of consumption, money, and leisure, but not the qualitative outcomes for different policies. To test this expectation I simulate the model by assigning diverse values to parameters. The results are given in Table 4. As we see the results are robust to changes in parameters, i.e., total welfare is maximized under disciplined fiscal policy and the ordering of policies under undisciplined fiscal policy does not change.

Parameters affect only the distribution of resources in the economy but not the relative performance of fiscal and monetary regimes. The effects of parameter changes on levels are reasonable. For example, if the representative agent puts more weight on money holdings $\left(\chi^{\prime}>\chi\right)$, the nominal value of money holdings and the total welfare increases while all other endogenous variables remain constant. This is the only case when a laissez-faire regime delivers a higher total welfare compared to other monetary regimes. The reason is straightforward: the regime that stabilizes 
Table 4: Robustness check

\begin{tabular}{|c|c|c|c|c|}
\hline & \multirow{2}{*}{$\begin{array}{l}\text { Disciplined } \\
\text { Fiscal } \\
\text { Authority }\end{array}$} & \multicolumn{3}{|c|}{ Undisciplined Fiscal Authority } \\
\hline & & $\begin{array}{c}\text { Fixed } \\
\text { Exchange Rate }\end{array}$ & $\begin{array}{c}\text { Fixed Price } \\
\text { Level }\end{array}$ & Laissez Faire \\
\hline \multicolumn{5}{|l|}{ Benchmark case } \\
\hline welfare cost of fluctuations & 0.0000 & 0.0001 & 0.0001 & 0.0002 \\
\hline total welfare & -4.4682 & -4.4806 & -4.4830 & -4.4866 \\
\hline \multicolumn{5}{|l|}{$\zeta^{\prime}=0.6 \quad(\zeta=1.15)$} \\
\hline welfare cost of fluctuations & 0.0000 & 0.0001 & 0.0001 & 0.0001 \\
\hline total welfare & -20.4640 & -20.4714 & -20.4734 & -20.4761 \\
\hline \multicolumn{5}{|l|}{$\chi^{\prime}=1 \quad(\chi=0.01)$} \\
\hline welfare cost of fluctuations & 0.0000 & 0.0005 & 0.0006 & 0.0002 \\
\hline total welfare & 482.6677 & 482.6082 & 482.6020 & 482.6500 \\
\hline \multicolumn{5}{|l|}{$\theta^{\prime}=0.6 \quad(\theta=0.4)$} \\
\hline welfare cost of fluctuations & 0.0000 & 0.0001 & 0.0001 & 0.0002 \\
\hline total welfare & 0.9127 & 0.8984 & 0.8974 & 0.8940 \\
\hline \multicolumn{5}{|l|}{$K^{\prime}=3 \quad(K=1.66)$} \\
\hline welfare cost of fluctuations & 0.0000 & 0.0001 & 0.0001 & 0.0002 \\
\hline total welfare & -4.4682 & -4.4806 & -4.4830 & -4.4866 \\
\hline \multicolumn{5}{|l|}{$\mathrm{A}^{\prime}=\mathrm{B}=2.16 ; \quad \mathrm{B}^{\prime}=\mathrm{A}=1.13$} \\
\hline welfare cost of fluctuations & 0.0000 & 0.0001 & 0.0001 & 0.0001 \\
\hline total welfare & -39.9431 & -39.9497 & -39.9503 & -39.9513 \\
\hline \multicolumn{5}{|l|}{$\alpha^{\prime}=\gamma=0.1 ; \quad \gamma^{\prime}=\alpha=0.4$} \\
\hline welfare cost of fluctuations & 0.0000 & 0.0001 & 0.0001 & 0.0001 \\
\hline total welfare & 13.2846 & 13.2774 & 13.2770 & 13.2743 \\
\hline
\end{tabular}

money supply has an advantage when money has unusually high weight in the utility function. Or if the share of tradable goods in the aggregate consumption $(\theta)$ is higher than the share of non-tradables (as opposed to the benchmark calibration where the representative household slightly puts more weight on non-tradable goods), the total welfare increases. This happens because the factors of production move towards the tradable sector in order to meet increased demand for manufactured goods. Or in the benchmark case we assumed that productivity is higher in the non-tradable sector $(A<B)$. If we assume the opposite $\left(A^{\prime}>B^{\prime}\right)$, the economy uses more factors of production to produce the tradable goods and the total welfare declines.

\section{Conclusion}

This paper evaluates the effectiveness of different monetary regimes in a resourcerich, small, and developing economy in a DSGE framework. The welfare analysis provided in this paper is non-rigorous and aims to shed new light on the specified role of certain monetary actions under certain conditions. In the presented model I 
mainly focus on the case where government spends revenues from natural resource exports without any discipline. In contrast, the monetary policy is set freely and the central bank independently chooses between one of three given regimes: (i) fixed exchange rate, (ii) price level targeting, and (iii) laissez-faire. Such a combination of fiscal and monetary policies is observed in most natural resource abundant developing countries.

The calibration and simulation of the model show that the exchange rate and price level targeting regimes outperform the laissez-faire regimes. In particular, I find that under these regimes consumption is smoothed and the domestic economy partially isolated from the fluctuations in revenues from natural resource exports. This is achieved through the intensive use of foreign exchange interventions by the central bank. Therefore the accumulation/decumulation of natural resource revenues in the form of central banks' international assets allows softening of the negative effects of Dutch Disease during high natural resource revenues and stabilizes the economy in the face of volatile natural resource revenues. Another important finding of the paper is that the economy is less vulnerable to shocks in foreign revenues under a fixed exchange rate regime than price level targeting. Hence a fixed exchange rate regime delivers the highest total welfare and the lowest welfare cost of a business cycle. The evaluation of the loss function highly depends on the central bank's preferences over output gap stabilization and inflation stabilization. These results confirm the effectiveness of particular monetary policies in the allocation problem when there are uncertain and huge natural resource revenues and undisciplined fiscal policy in the short run.

The findings of this paper provide support for the central bank targeting exchange rate stability when the government pursues fiscal expansion. The model depicts the situation observed in Azerbaijan, an oil and gas rich developing postSoviet economy during the last decade. However, the results of the paper can be applied to other natural resource rich developing economies and also to aid receiving countries due to similarities between aid and natural resource revenue inflows.

There are several perspectives for future research on this topic and the model 
can be enriched by introducing additional assumptions. For example, it might be of some interest to include prudential investment and hybrid monetary rules in the model. It will enable estimating an optimal spending-saving strategy from the fiscal policy perspective and a precise exchange rate regime from the monetary policy perspective. Such an assumption will improve the results because in reality not all natural-resource revenues are inefficiently spent, and the central banks never pursue a single pure target at one time. 


\section{References}

Acosta, P.A., Lartey, E.K.K., and Mandelman, F.S. (2009): "Remittances and the Dutch Disease", Journal of International Economics, 79, 102-116.

Adam, C., O'Connell, S., Buffie, E., and Pattillo, C. (2009): "Monetary Policy Rules for Managing Aid Surges in Africa", Review of Development Economics.

Aliyev, I. (2012): "Is Fiscal Policy Procyclical in Resource-Rich Countries?", CERGE-EI Working Paper, No 464.

Auty, R. (2001a): Resource Abundance and Economic Development, Oxford University Press.

Auty, R. (2001b): "The Political Economy of Resource-driven Growth", European Economic Review, 45 839-846.

Auty, R. (1993): Sustaining Development in Mineral Economies: The Resource Curse Thesis, London, Routledge.

Barnett, S., and Ossowski, R. (2003): "Operational Aspects of Fiscal Policy in Oil-producing Countries" in Davis, J., Ossowski, R., and Fedelino, A. (eds.), Fiscal Policy Formulation and Implementation in Oil-Producing Countries, IMF, Washington, D.C.

Benkhodja, M. T. (2011): "Monetary Policy and the Dutch Disease in a Small Open Oil Exporting Economy", Gate Working Paper, No. 1134.

Cerny, A., and Filer, R. (2007): "Natural Resources: Are They Really a Curse?", CERGE-EI Working Paper, No 321.

Cooley, T. F., and Hansen, G. D. (1989): "The Inflation Tax in a Real Business Cycle Model", American Economic Review, 79:733-48.

Corden, W. M. (1981): "Exchange Rate Protection", Cooper et al.: The international Monetary System under Flexible Exchange rates: Global, Regional and national, Essays in Honour of Robert Tiffin, Cambridge.

Corden, M., and Neary, P. (1982): "Booming Sector and De-industrialization in a Small Open Economy", Economic Journal, 92, 825-848.

Corden, W. M. (1982): "Exchange Rate Policy and Resource Boom", Economic Record, 58 (March), 19-31. 
Corden, W. M. (1984) "Booming Sector and Dutch Disease Economics: Survey and Consolidation", Oxford Economic Papers, 36, 359-380.

Corden, W.M. (1994): Economic Policy, Exchange Rates, and the International System, Oxford University Press, and University of Chicago Press.

Corden, W. M. (1997): Trade Policy and Economic Welfare, second edition, Oxford University Press.

Davis, J. M., Ossowski, R., and Fedelino, A. (2003): "Fiscal Policy Formulation and Implementation in Oil-Producing Countries", IMF, Publication Services.

Da Costa, M., and Olivo, V. (2008): "Constraints on the Design and Implementation of Monetary Policy in Oil Economies", IMF Working Paper, WP/08/142.

Gali, J. (2008): Monetary Policy, Inflation and Business Cycle, Princeton University Press.

Gylfason, T., Herbertsson, T.T., and Zoega, G. (1997): "A Mixed Blessing: Natural Resources and Economic Growth", CEPR Discussion Paper, No 1668.

Hermann, E. F. (2006): "Spending Natural Resource Revenues in an Altruistic Growth Model", EPRU Working Paper Series, 06.09.

Ho, W-M. (2004): "The Liquidity Effects of Foreign Exchange Intervention", Journal of International Economics, 63, 179- 208.

Husain, A. M., Tazhibayeva, K., and Ter-Martirosyan, A. (2008): "Fiscal Policy and Economic Cycles in Oil-Exporting Countries", IMF Working Paper, WP/08/253.

Karl, T. L. (1997): The Paradox of Plenty: Oil Booms, Venezuela, and Other Petro-States, University of California Press.

Koeda, J., and Kramarenko, V. (2008): "Impact of Government Expenditure on Growth: The Case of Azerbaijan", IMF Working Paper, WP/08/115.

Lama, R., and Medina, P. (2010): "Is Exchange Rate Stabilization an Appropriate Cure for the Dutch Disease?", IMF Working Paper, WP/10/182.

Larsen, E. R. (2004): "Escaping the Resource Curse and the Dutch Disease? When and Why Norway Caught up with and Forged ahead of Its Neighbors", Statistics Norway, Research Department Discussion Papers, No. 377.

Lartey, E. K. K. (2008): "Capital Inflows, Dutch Disease Effects, and Monetary 
Policy in a Small Open Economy", Review of International Economics, 16(5), 971989.

Lucas, Robert, E. Jr. (1987): Models of Business Cycles, New York: Basic Blackwell.

Obstfeld, M., and Rogoff, K. (1994): "Exchange Rate Dynamics Redux", NBER Working Paper, No 4693.

Ploeg, F., and Venables, A. (2009): "Harnessing Windfall Revenues: Optimal Policies for Resource-Rich Developing Economies", CESifo Working Paper, No. 2571 .

Prati, A., and Tressel, T. (2006): "Aid Volatility and Dutch Disease: Is There a Role for Macroeconomic Policies?" IMF Working Paper, WP/06/145.

Resende, De C., and Rebei, N. (2008): "The Welfare Implications of Fiscal Dominance", Bank of Canada Working Paper, 2008-28.

Sachs, J. D., and Warner, A. M. (1995): "Natural Resource Abundance and Economic Growth", Development discussion paper, no. 517a.

Sachs, J. D., and Warner, A. M. (2001): "Natural Resources and Economic Development: The curse of natural resources", European Economic Review, 45:827838.

Segura, A. (2006): "Management of Oil Wealth Under the Permanent Income Hypothesis: The Case of São Tomé and Príncipe", Working Paper No. 06/183, International Monetary Fund, Washington, D.C.

Setser, B. (2007): "The Case for Exchange Rate Flexibility in Oil-Exporting Economies", Peterson Institute, No PB07-8, 2007.

Sidrauski, M. (1967): "Rational Choice and Patterns of Growth in a Monetary Economy", The American Economic Review, Vol. 57, No. 2, pp. 534-544.

Sosunov, K., and Zamulin, O. (2007): "Monetary Policy in Economy Sick with Dutch Disease", CEFIR/NES Working Paper Series, No 101.

Stevens, P. (2003): "Resource Impact: Curse or Blessing?, A Literature Survey", Journal of Energy Literature, 9 (1), pp. 3-42.

Svensson, L. (1997): "Inflation Targeting, Some Extensions", NBER working 
paper, No. 6545.

Walsh, Carl, E. (2003): Monetary Theory and Policy, MIT.

Wijnbergen, V. S. (1984): "Inflation, Employment, and the Dutch Disease in Oil-Exporting Countries: A Short-Run Disequilibrium Analysis", The Quarterly Journal of Economics, Vol. 99, No. 2, pp. 233-250.

Woodford, M. (2003): Interest and Prices, Princeton University Press. 


\section{Appendix 1. Solution of the Households' Problem}

The representative household solves the following maximization problem:

$$
\underset{\left\{C_{t}^{M}, C_{t}^{N}, M_{t}, L_{t}\right\}}{\operatorname{Max}} E_{t} \sum_{t=0}^{\infty} \beta^{t}\left[\zeta \operatorname{Ln}\left(C_{t}\right)+\chi \operatorname{Ln}\left(\frac{M_{t}}{P_{t}}\right)+\psi \operatorname{Ln}\left(1-L_{t}\right)\right],
$$

subject to budget constraint

$M_{t-1}+e_{t} \tau_{t} F_{t}+W_{t} L_{t}+R_{t} K_{t}+\Pi_{t}=M_{t}+e_{t} C_{t}^{M}+P_{t}^{N} C_{t}^{N}$.

Langrangean can be written as

$$
\begin{aligned}
L= & \sum_{t=0}^{\infty} \beta^{t}\left\{\left[\zeta \operatorname{Ln}\left(\frac{\left(C_{t}^{M}\right)^{\theta}\left(C_{t}^{N}\right)^{1-\theta}}{\theta^{\theta}(1-\theta)^{1-\theta}}\right)+\chi \operatorname{Ln}\left(\frac{M_{t}}{P_{t}}\right)+\psi \operatorname{Ln}\left(1-L_{t}\right)\right]\right. \\
& \left.+\vartheta_{t}\left[M_{t-1}+e_{t} \tau_{t} F_{t}+W_{t} L_{t}+R_{t} K+\Pi_{t}-M_{t}-e_{t} C_{t}^{M}-P_{t}^{N} C_{t}^{N}\right]\right\} .
\end{aligned}
$$

Now we can derive the first order conditions:

$$
\begin{gathered}
{\left[C_{t}^{M}\right]: \beta^{t} \zeta \theta \frac{1}{C_{t}^{M}}-\beta^{t} \vartheta_{t} e_{t}=0} \\
{\left[C_{t}^{N}\right]: \beta^{t} \zeta(1-\theta) \frac{1}{C_{t}^{N}}-\beta^{t} \vartheta_{t} P_{t}^{N}=0 ;} \\
{\left[M_{t}\right]: \beta^{t} \chi \frac{1}{M_{t}}+\beta^{t+1} \vartheta_{t+1}-\beta^{t} \vartheta_{t}=0 ;} \\
{\left[L_{t}\right]:-\beta^{t} \psi \frac{1}{1-L_{t}}+\beta^{t} \vartheta_{t} W_{t}=0 ;}
\end{gathered}
$$




$$
\left[\vartheta_{t}\right]: M_{t-1}+e_{t} \tau_{t} F_{t}+W_{t} L_{t}+R_{t} K+\Pi_{t}-M_{t}-e_{t} C_{t}^{M}-P_{t}^{N} C_{t}^{N}=0 .
$$

Further simplification gives us the following equations:

$$
\begin{gathered}
\frac{\zeta \theta}{e_{t} C_{t}^{M}}=\vartheta_{t} ; \\
\frac{1-\theta}{P_{t}^{N} C_{t}^{N}}=\frac{\theta}{e_{t} C_{t}^{M}} ; \\
\frac{\chi}{M_{t}}=\frac{\zeta \theta}{e_{t} C_{t}^{M}}-\beta \frac{\zeta \theta}{e_{t+1} C_{t+1}^{M}} ; \\
\frac{\psi}{1-L_{t}}=\frac{\zeta \theta}{e_{t} C_{t}^{M}} W_{t} .
\end{gathered}
$$

We can write these conditions as

$\frac{\chi}{M_{t}}+\beta \frac{\zeta \theta}{e_{t+1} C_{t+1}^{M}}-\frac{\zeta \theta}{e_{t} C_{t}^{M}}=0$

$C_{t}^{M}=\theta\left(\frac{P_{t}^{N}}{e_{t}}\right)^{1-\theta} C_{t}$,

$\frac{\chi}{M_{t}}+\beta \frac{\zeta \theta}{e_{t+1} \theta\left(\frac{P_{t+1}^{N}}{e_{t+1}}\right)^{1-\theta} C_{t+1}}-\frac{\zeta \theta}{e_{t} \theta\left(\frac{P_{t}^{N}}{e_{t}}\right)^{1-\theta} C_{t}}=0$.

We can use the aggregate price index (derived in Appendix 2) to get

$\frac{\chi}{M_{t}}+\beta \frac{\zeta}{P_{t+1} C_{t+1}}-\frac{\zeta}{P_{t} C_{t}}=0$

or

$\frac{\zeta}{P_{t} C_{t}}=\beta \frac{\zeta}{P_{t+1} C_{t+1}}+\frac{\chi}{M_{t}}$.

Iterating this equation to one period forward yields

$\frac{\zeta}{P_{t+1} C_{t+1}}=\beta \frac{\zeta}{P_{t+2} C_{t+2}}+\frac{\chi}{M_{t+1}} ;$ 
$\frac{\zeta}{P_{t} C_{t}}=\beta\left(\beta \frac{\zeta}{P_{t+2} C_{t+2}}+\frac{\chi}{M_{t+1}}\right)+\frac{\chi}{M_{t}}=\beta^{2} \frac{\zeta}{P_{t+2} C_{t+2}}+\beta \frac{\chi}{M_{t+1}}+\frac{\chi}{M_{t}}$,

and

$\frac{\zeta}{P_{t+2} C_{t+2}}=\beta \frac{\zeta}{P_{t+3} C_{t+3}}+\frac{\chi}{M_{t+2}}$

$\frac{\zeta}{P_{t} C_{t}}=\beta \frac{\zeta}{P_{t+1} C_{t+1}}+\frac{\chi}{M_{t}}=\beta\left(\beta \frac{\zeta}{P_{t+2} C_{t+2}}+\frac{\chi}{M_{t+1}}\right)+\frac{\chi}{M_{t}}$

$=\beta\left(\beta\left(\beta \frac{\zeta}{P_{t+3} C_{t+3}}+\frac{\chi}{M_{t+2}}\right)+\frac{\chi}{M_{t+1}}\right)+\frac{\chi}{M_{t}}=\beta^{3} \frac{\zeta}{P_{t+3} C_{t+3}}+\beta^{2} \frac{\chi}{M_{t+2}}+\beta \frac{\chi}{M_{t+1}}+\frac{\chi}{M_{t}}$.

If we continue these steps for infinite periods we get

$\frac{\zeta}{P_{t} C_{t}}=\chi E_{t} \sum_{j=0}^{\infty} \beta^{j} \frac{1}{M_{t+j}}$.

From (2) we get $C_{t}^{N}=\frac{(1-\theta) e_{t} C_{t}^{M}}{\theta P_{t}^{N}}$, and we replace it in the formula for aggregate consumption to get

$C_{t}^{M}=\theta\left(\frac{P_{t}^{N}}{e_{t}}\right)^{1-\theta} C_{t}$

We substitute it in (4) and after some simple algebra we get

$\frac{\psi}{\zeta}=\frac{W_{t}\left(1-L_{t}\right)}{P_{t} C_{t}}$. 


\section{Appendix 2. Derivation of the Price Index}

The consumption-based price index solves following minimization problem:

$P_{t} C_{t}=\operatorname{Min}\left(P_{t}^{M} C_{t}^{M}+P_{t}^{N} C_{t}^{N}\right)$

s.t. $\frac{\left(C_{t}^{M}\right)^{\theta}\left(C_{t}^{N}\right)^{1-\theta}}{\theta^{\theta}(1-\theta)^{1-\theta}}=1$.

The first order conditions yield

$\frac{(1-\theta)}{\theta} \frac{P_{t}^{M}}{P_{t}^{N}}=\frac{C_{t}^{N}}{C_{t}^{M}}$.

In the optimal solution we can write

$P_{t} \frac{\left(C_{t}^{M}\right)^{\theta}\left(C_{t}^{N}\right)^{1-\theta}}{\theta^{\theta}(1-\theta)^{1-\theta}}=P_{t}^{M} C_{t}^{M}+P_{t}^{N} C_{t}^{N}$.

Dividing both sides by $C_{t}^{M}$ gives us

$P_{t} \frac{\left(C_{t}^{M}\right)^{\theta-1}\left(C_{t}^{N}\right)^{1-\theta}}{\theta^{\theta}(1-\theta)^{1-\theta}}=P_{t}^{M}+P_{t}^{N} \frac{C_{t}^{N}}{C_{t}^{M}}$.

using FOC we get

$P_{t} \frac{\left(\frac{(1-\theta)}{\theta} \frac{P_{t}^{M}}{P_{t}^{N}}\right)^{1-\theta}}{\theta^{\theta}(1-\theta)^{1-\theta}}=P_{t}^{M}+P_{t}^{N} \frac{(1-\theta)}{\theta} \frac{P_{t}^{M}}{P_{t}^{N}}$

After some simplification we end up with the equation for aggregate price index: $P_{t}=\left(P_{t}^{M}\right)^{\theta}\left(P_{t}^{N}\right)^{1-\theta}$. 


\section{Appendix 3. Solution of the Firms' Problem}

Maximization of the firms' problem yields

$$
\begin{gathered}
\underset{\left\{K_{t}^{M}, L_{t}^{M}\right\}}{\operatorname{Max}}\left\{P_{t}^{M} A\left(K_{t}^{M}\right)^{\alpha}\left(L_{t}^{M}\right)^{1-\alpha}-R_{t} K_{t}^{M}-W_{t} L_{t}^{M}\right\} ; \\
{\left[K_{t}^{M}\right]: \alpha P_{t}^{M} A\left(K_{t}^{M}\right)^{\alpha-1}\left(L_{t}^{M}\right)^{1-\alpha}=R_{t} ;} \\
{\left[L_{t}^{M}\right]:(1-\alpha) P_{t}^{M} A\left(K_{t}^{M}\right)^{\alpha}\left(L_{t}^{M}\right)^{-\alpha}=W_{t} ;} \\
\left\{K_{t}^{N} L_{t}^{N}\right\} \\
{\left[P_{t}^{N} B\left(K_{t}^{N}\right)^{\gamma}\left(L_{t}^{N}\right)^{1-\gamma}-R_{t} K_{t}^{N}-W_{t} L_{t}^{N}\right\} ;} \\
{\left[K_{t}^{N}\right] \quad: \quad \gamma P_{t}^{N} B\left(K_{t}^{N}\right)^{\gamma-1}\left(L_{t}^{N}\right)^{1-\gamma}=R_{t} ;} \\
{\left[L_{t}^{N}\right] \quad: \quad(1-\gamma) P_{t}^{N} B\left(K_{t}^{N}\right)^{\gamma}\left(L_{t}^{N}\right)^{-\gamma}=W_{t} .}
\end{gathered}
$$

Equating (17) with (20) and (18) with (21) we get

$$
\begin{gathered}
\alpha P_{t}^{M} A\left(K_{t}^{M}\right)^{\alpha-1}\left(L_{t}^{M}\right)^{1-\alpha}=\gamma P_{t}^{N} B\left(K_{t}^{N}\right)^{\gamma-1}\left(L_{t}^{N}\right)^{1-\gamma}, \\
(1-\alpha) P_{t}^{M} A\left(K_{t}^{M}\right)^{\alpha}\left(L_{t}^{M}\right)^{-\alpha}=(1-\gamma) P_{t}^{N} B\left(K_{t}^{N}\right)^{\gamma}\left(L_{t}^{N}\right)^{-\gamma} \\
\frac{\alpha L_{t}^{M}}{(1-\alpha) K_{t}^{M}}=\frac{\gamma L_{t}^{N}}{(1-\gamma) K_{t}^{N}},
\end{gathered}
$$

or

$$
\frac{K_{t}^{M}}{L_{t}^{M}}=\frac{\alpha(1-\gamma) K_{t}^{N}}{\gamma(1-\alpha) L_{t}^{N}}
$$

We replace $\frac{K_{t}^{M}}{L_{t}^{M}}$ in (23) using (25) to get 
$\left(\frac{\alpha}{\gamma}\right)^{\alpha}\left(\frac{(1-\gamma)}{(1-\alpha)}\right)^{\alpha-1} \frac{A}{B}\left(\frac{K_{t}^{N}}{L_{t}^{N}}\right)^{\alpha-\gamma}=\frac{P_{t}^{N}}{P_{t}^{M}}$,

or

$\left(\frac{\alpha}{\gamma}\right)^{\alpha}\left(\frac{(1-\gamma)}{(1-\alpha)}\right)^{\alpha-1} \frac{A}{B}\left(\frac{K_{t}^{N}}{L_{t}^{N}}\right)^{\alpha-\gamma}=\left(\frac{P_{t}}{e_{t}}\right)^{\frac{1}{1-\theta}}$.

As we see $\alpha$ and $\gamma$ determine how the price ratio is related to the capital-labor ratio. To understand how it works let's assume that there is an increase in the capital-labor ratio in the non-tradable sector driven by a rise in the natural resource revenues. Under a fixed exchange regime if $\alpha>\gamma, P_{t}$ increases, and if $\alpha<\gamma, P_{t}$ decreases. 


\section{Appendix 4. Structural Form of the Model}

- endogenous variables: $C_{t}, C_{t}^{M}, C_{t}^{N}, e_{t}, P_{t}, P_{t}^{M}, P_{t}^{N}, M_{t}, L_{t}, L_{t}^{M}, L_{t}^{N}, K_{t}^{M}, K_{t}^{N}, W_{t}$, $R_{t}, \Phi_{t}, S_{t}, Y, Y^{M}, Y^{N}$

- exogenous variables: $F_{t}, \tau_{t}, \mu_{t}$

- parameters: $\alpha, \gamma, \beta, \zeta, \theta, \chi, \psi, K, A, B$

1. $C_{t}=\frac{\left(C_{t}^{M}\right)^{\theta}\left(C_{t}^{N}\right)^{1-\theta}}{\theta^{\theta}(1-\theta)^{1-\theta}}$

2. $\frac{1-\theta}{P_{t}^{N} C_{t}^{N}}=\frac{\theta}{e_{t} C_{t}^{M}}$

3. $\frac{\chi}{M_{t}}+\beta \frac{\zeta}{P_{t+1} C_{t+1}}-\frac{\zeta}{P_{t} C_{t}}=0$

4. $\frac{\psi}{\zeta}=\frac{W_{t}\left(1-L_{t}\right)}{P_{t} C_{t}}$

5. $P_{t}^{M}=e_{t}$

6. $P_{t}=\left(P_{t}^{M}\right)^{\theta}\left(P_{t}^{N}\right)^{1-\theta}$

7. $C_{t}^{M}=A\left(K_{t}^{M}\right)^{\alpha}\left(L_{t}^{M}\right)^{1-\alpha}+\left(\tau_{t}-\mu_{t}\right) F_{t}$

8. $C_{t}^{N}=B\left(K_{t}^{N}\right)^{\gamma}\left(L_{t}^{N}\right)^{1-\gamma}$

9. $\alpha P_{t}^{M} A\left(K_{t}^{M}\right)^{\alpha-1}\left(L_{t}^{M}\right)^{1-\alpha}=R_{t}$

10. $\gamma P_{t}^{N} B\left(K_{t}^{N}\right)^{\gamma-1}\left(L_{t}^{N}\right)^{1-\gamma}=R_{t}$

11. $(1-\alpha) P_{t}^{M} A\left(K_{t}^{M}\right)^{\alpha}\left(L_{t}^{M}\right)^{-\alpha}=W_{t}$

12. $(1-\gamma) P_{t}^{N} B\left(K_{t}^{N}\right)^{\gamma}\left(L_{t}^{N}\right)^{-\gamma}=W_{t}$

13. $\Phi_{t}=\Phi_{t-1}+\left(1-\tau_{t}\right) F_{t}$. 
14. $M_{t}=M_{t-1}+e_{t} \mu_{t} F_{t}$

15. $S_{t}=S_{t-1}+\mu_{t} F_{t}$

16. $\bar{K}=K_{t}^{M}+K_{t}^{N}$

17. $L_{t}=L_{t}^{M}+L_{t}^{N}$

18. $Y_{t}=Y_{t}^{M}+Y_{t}^{N}$

19. $Y_{t}^{M}=A\left(K_{t}^{M}\right)^{\alpha}\left(L_{t}^{M}\right)^{1-\alpha}$

20. $Y_{t}^{N}=\frac{P_{t}^{N}}{e} B\left(K_{t}^{N}\right)^{\gamma}\left(L_{t}^{N}\right)^{1-\gamma}$.

In the steady state $F$ is fixed, the fiscal authority and the central bank do not take any action, and consequently $\tau_{t}$ equals one and $\mu_{t}$ equals zero and all endogenous variables are constant. Therefore in the steady-state we have the following.

1. $\bar{C}=\frac{\left(\bar{C}^{M}\right)^{\theta}\left(\bar{C}^{N}\right)^{1-\theta}}{\theta^{\theta}(1-\theta)^{1-\theta}}$

2. $\frac{1-\theta}{\bar{P}^{N} \bar{C}^{N}}=\frac{\theta}{\bar{e} \bar{C}^{M}}$

3. $\frac{\chi}{\bar{M}}-(1-\beta) \frac{\zeta}{P C}=0$

4. $\frac{\psi}{\zeta}=\frac{\bar{W}(1-\bar{L})}{\overline{P C}}$

5. $\bar{P}^{M}=\bar{e}$

6. $\bar{P}=\left(\bar{P}^{M}\right)^{\theta}\left(\bar{P}^{N}\right)^{1-\theta}$

7. $\bar{C}^{M}=A\left(\bar{K}^{M}\right)^{\alpha}\left(\bar{L}^{M}\right)^{1-\alpha}+\bar{F}$

8. $\bar{C}^{N}=B\left(\bar{K}^{N}\right)^{\gamma}\left(\bar{L}^{N}\right)^{1-\gamma}$ 
9. $\alpha \bar{P}^{M} A\left(\bar{K}^{M}\right)^{\alpha-1}\left(\bar{L}^{M}\right)^{1-\alpha}=\bar{R}$

10. $\gamma \bar{P}^{N} B\left(\bar{K}^{N}\right)^{\gamma-1}\left(\bar{L}^{N}\right)^{1-\gamma}=\bar{R}$

11. $(1-\alpha) \bar{P}^{M} A\left(\bar{K}^{M}\right)^{\alpha}\left(\bar{L}^{M}\right)^{-\alpha}=\bar{W}$

12. $(1-\gamma) \bar{P}^{N} B\left(\bar{K}^{N}\right)^{\gamma}\left(\bar{L}^{N}\right)^{-\gamma}=\bar{W}$

13. $\bar{Y}=\bar{Y}^{M}+\bar{Y}^{N}$

14. $\bar{Y}^{M}=A\left(\bar{K}^{M}\right)^{\alpha}\left(\bar{L}^{M}\right)^{1-\alpha}$

15. $\bar{Y}^{N}=\frac{\bar{P}^{N}}{\bar{P}^{M}} B\left(\bar{K}^{N}\right)^{\gamma}\left(\bar{L}^{N}\right)^{1-\gamma}$

16. $\bar{\mu}=0$

17. $\bar{\tau}=1$

18. $\bar{K}=\bar{K}^{M}+\bar{K}^{N}$

19. $\bar{L}=\bar{L}^{M}+\bar{L}^{N}$. 
Appendix 5. Derivation of the formula for the welfare cost of the business cycle:

$$
\begin{aligned}
& E_{0} \sum_{t=0}^{\infty} \beta^{t}\left[\zeta \operatorname{Ln}(\bar{C})+\chi \operatorname{Ln}\left(\frac{\bar{M}}{\bar{P}}\right)+\psi \operatorname{Ln}(1-\bar{L})\right]- \\
& E_{0} \sum_{t=0}^{\infty} \beta^{t}\left[\zeta \operatorname{Ln}\left(C_{t}(1+\eta)\right)+\chi \operatorname{Ln}\left(\frac{M t}{P_{t}}\right)+\psi \operatorname{Ln}\left(1-L_{t}\right)\right]=0
\end{aligned}
$$

$\sum_{t=0}^{\infty} \beta^{t} \zeta \operatorname{Ln}(1+\eta)=$

$E_{0} \sum_{t=0}^{\infty} \beta^{t}\left[\zeta \operatorname{Ln}(\bar{C})+\chi \operatorname{Ln}\left(\frac{\bar{M}}{\bar{P}}\right)+\psi \operatorname{Ln}(1-\bar{L})\right]-E_{0} \sum_{t=0}^{\infty} \beta^{t}\left[\zeta \operatorname{Ln}\left(C_{t}\right)+\chi \operatorname{Ln}\left(\frac{M_{t}}{P_{t}}\right)+\psi \operatorname{Ln}\left(1-L_{t}\right)\right] ;$

1.

$\eta=\exp \left\{\frac{E_{0} \sum_{t=0}^{\infty} \beta^{t}\left[\zeta \operatorname{Ln}(\bar{C})+\chi \operatorname{Ln}\left(\frac{\bar{M}}{\bar{P}}\right)+\psi \operatorname{Ln}(1-\bar{L})\right]-E_{0} \sum_{t=0}^{\infty} \beta^{t}\left[\zeta \operatorname{Ln}\left(C_{t}\right)+\chi \operatorname{Ln}\left(\frac{M_{t}}{P_{t}}\right)+\psi \operatorname{Ln}\left(1-L_{t}\right)\right]}{\zeta \sum_{t=0}^{\infty} \beta^{t}}\right\}-$ 
Working Paper Series

ISSN 1211-3298

Registration No. (Ministry of Culture): E 19443

Individual researchers, as well as the on-line and printed versions of the CERGE-EI Working Papers (including their dissemination) were supported from the European Structural Fund (within the Operational Programme Prague Adaptability), the budget of the City of Prague, the Czech Republic's state budget and the following institutional grants:

- Center of Advanced Political Economy Research [Centrum pro pokročilá politickoekonomická studia], No. LC542, (2005-2011);

Specific research support and/or other grants the researchers/publications benefited from are acknowledged at the beginning of the Paper.

(c) Ruslan Aliyev, 2012

All rights reserved. No part of this publication may be reproduced, stored in a retrieval system or transmitted in any form or by any means, electronic, mechanical or photocopying, recording, or otherwise without the prior permission of the publisher.

Published by

Charles University in Prague, Center for Economic Research and Graduate Education (CERGE) and

Economics Institute ASCR, v. v. i. (EI)

CERGE-El, Politických vězňů 7, 11121 Prague 1, tel.: +420 224005 153, Czech Republic.

Printed by CERGE-EI, Prague

Subscription: CERGE-EI homepage: http://www.cerge-ei.cz

Phone: + 420224005153

Email: office@cerge-ei.cz

Web: http://www.cerge-ei.cz

Editor: Michal Kejak

Editorial board: Jan Kmenta, Randall Filer, Petr Zemčík

The paper is available online at http://www.cerge-ei.cz/publications/working_papers/.

ISBN 978-80-7343-270-6 (Univerzita Karlova. Centrum pro ekonomický výzkum a doktorské studium)

ISBN 978-80-7344-262-0 (Národohospodářský ústav AV ČR, v. v. i.) 
CERGE-EI

P.O.BOX 882

Politických vězňů 7

11121 Praha 1

Czech Republic http://www.cerge-ei.cz 